\title{
Lisbon Before the Courts: Comparative Perspectives
}

\author{
Mattias Wendel*
}

\begin{abstract}
Lisbon decisions of the constitutional courts in Austria, the Czech Republic, France, Germany, Hungary, Latvia and Poland from a comparative perspective - Democracy, sovereignty and identity - Permeability of national and supranational law Ratification of the Lisbon Treaty and its constitutional foundations - Procedural background and legal outcome of the Lisbon decisions - Differences of institutional self-conception - Parliamentary responsibility for integration - Prior parliamentary assent to the future application of 'dynamic treaty provisions' - Different conceptions of national and multi-levelled democracy - Popular vote - Constitutional limits to European integration - Limits indicating the necessity of an amendment and limits protecting the inalienable substantial core of a constitutional order - German Bundesverfassungsgericht only court in Europe spelling out an eternity clause in a detailed, catalogue style manner - Judicial restraint - Ultra vires and identity review - Article 4.2 TEU as an integration clause of EU law and not a derogation clause - Comparative dialectics
\end{abstract}

\section{INTRODUCTION}

The constitutional foundations of European integration have been subject to farreaching transformation. The entry into force of the Lisbon Treaty on 1 December 2009 is a milestone in this ongoing journey. However, the reform of European Union treaty law is just one, albeit important stone in the game. Focusing exclusively on the treaty changes does not capture the whole picture, for the remarkable development of national constitutional law has shaped and conditioned the reform of European constitutional law just as well. The activities on the Union and on

* Dr. iur. (Humboldt-University Berlin), Maitrise en droit (Paris 1), research assistant and lecturer, Walter-Hallstein-Institute for European Constitutional Law (WHI), Humboldt-University Berlin, contact: mattias.wendel@staff.hu-berlin.de. This article goes back to a paper presented at the $8^{\text {th }}$ conference of the European Constitutional Law Network (ECLN) 2010 in Madrid. For helpful suggestions on earlier drafts I would like to thank Alexander Daniel, Edgar Lenski and JanHerman Reestman. 
the member state levels were closely interrelated and may literally be told as a story of 'multilevel-constitutionalism in action.'

A considerable part of today's national constitutional law relating to the European Union has found its current shape in recent times. Many of the Central and Eastern European countries that joined the Union in 2004 and 2007 enacted new integration clauses in their constitutions providing the normative basis for Union membership. ${ }^{2}$ However, founding members such as France and Germany as well as 'old' member states such as Ireland and Portugal also passed important EUrelated amendments. Here, the provisions regulating the constitutional permeability $^{3}$ for supranational law were significantly reframed in the course of the ratification of the Constitutional Treaty and the Lisbon Treaty. ${ }^{4}$ This process of adjustment is continuing. In July 2010 the Austrian legislation passed a detailed constitutional amendment with regard to parliamentary rights in EU matters. ${ }^{5}$ In Sweden, the modernization of EU related articles is expected to come into force on 1 January 2011, as a part of a major constitutional reform package. ${ }^{6}$ In other countries, there are calls for the introduction of explicit EU provisions in the constitution as well. ${ }^{7}$

Alongside the textual evolution, national supreme jurisdictions all over Europe have delivered an unprecedented series of landmark decisions within a relatively short period of time. These decisions address key questions of European constitutionalism. Just recall the declaration of the Spanish Constitutional Tribunal on the Constitutional Treaty in 2004 with its already famous distinction between

${ }^{1}$ I. Pernice, 'The Treaty of Lisbon: Multilevel constitutionalism in Action', 15 CJEL (2009) p. 349 et seq.

${ }^{2}$ See on that A.E. Kellermann et al. (eds.), EU-Enlargement - The Constitutional Impact at EU and National Level (T.M.C. Asser Press 2001); id. et al. (eds.), The Impact of EU Accession on the Legal Orders of New Member States and (Pre-)Candidate Countries (T.M.C. Asser Press 2006); A. Albi, EU Enlargement and the Constitutions of Central and Eastern Europe (Cambridge University Press 2005) p. 67-121; id., "Europe" Articles in the Constitutions of Central and Eastern European Countries', 42 CMLRev (2005) p. 399 et seq.

${ }^{3}$ For the concept of constitutional permeability, see M. Wendel, Permeabilität im europäischen Verfassungsrecht (Mohr Siebeck 2011, forthcoming), ch. 1.

${ }^{4}$ For a systematic analysis of integration clauses in the constitutions of the EU Member States cf. Wendel, supra n. 3, chs. 4-11. For an overview, see C. Grabenwarter, 'National Constitutional Law Relating to the European Union', in A. v. Bogdandy and J. Bast (eds.), Principles of European Constitutional Law, $2^{\text {nd }}$ edn. (Hart 2009) p. 83 et seq.

${ }^{5}$ Federal constitutional law, Austrian federal law gazette I No 57/2010.

${ }^{6}$ Bill No. 2009/10:80. The bill includes the introduction of a general clause indicating Sweden's Membership in the EU (future Ch. $1 \$ 10$ of the Swedish 'Form of Government') as well as the reform of the existing integration clause (currently Ch. $10 \$ 5$, in future Ch. $10 \$ 6$ ). For information about the reform I would like to thank Carl Fredrik Bergström.

${ }^{7}$ An example is Spain, where the Spanish State Council (Consejo de Estado) pleaded as early as 2006 for the introduction of a new and explicit 'Europe-clause' in its opinion of 16 Feb. 2006, No. E 1/2005, available at <www.consejo-estado.es/pdf/modificaciones\%20constitucion\%20esp.pdf>. 
primacy (primacia) and supremacy (supremacia). ${ }^{8}$ Similarly, the decision of the Polish Constitutional Tribunal on the accession treaty in $2005,{ }^{9}$ the sugar quota cases in Hungary, Estonia and the Czech Republic from 2004 to $2006^{10}$ and the Arrest Warrant decisions in Poland, Germany, Cyprus and the Czech Republic between 2005 and 2006 are worth noting. ${ }^{11}$ Not to forget about the French Conseil constitutionnel which, in 2004, delivered not only a leading case on the Constitutional Treaty, ${ }^{12}$ but also started an entirely new generation of decisions related to the transposition of directives, ${ }^{13}$ followed by the French Conseil d'Etat in its landmark decisions Arcelor in $2007^{14}$ and Perreux in 2009. ${ }^{15}$ Another major decision was delivered recently by the German Bundesverfassungsgericht. By order of 6 July 2010 in the case of Honeywell it has set up important procedural and substantive limits to the exercise of ultra vires review in Germany. ${ }^{16}$

${ }^{8}$ Spanish CT, Case 1/2004 Constitutional Treaty, declaration of 13 Dec. 2004, with case notes of F. Castillo de la Torre, 42 CMLRev (2005) p. 1169 et seq., C.B. Schutte, 1 EuConst (2005) p. 281 et seq. and A.C. Becker, $E u R(2005)$ p. 353 et seq.

${ }^{9}$ Polish CT, Case K 18/04 Accession Treaty, judgment of 11 May 2005. An English summary is available at: <www.trybunal.gov.pl/eng/summaries/documents/K_18_04_GB.pdf>. For comments, see M. Bainczyk and U. Ernst, EuR (2006) p. 247 et seq.; A. Łazowski, 3 EuConst (2007) p. 148 et seq.; S. Biernat, 'Offene Staatlichkeit', in A. v. Bogdandy and P.M. Huber (eds.), Ius Publicum Europaeum, Vol. 2 (C.F. Müller 2008) \$21 Polen, para. 45.

${ }^{10}$ For a comparative analysis, see A. Albi, 'Ironies in Human Rights Protection in the EU: PreAccession Conditionality and Post-Accession Conundrums', 15 ELJ (2009) p. 46, 52 et seq.; id., 'Supremacy of EC Law in the New Member States', 3 EuConst (2007) p. 25, 48 et seq.; W. Sadurski, "Solange, chapter 3": Constitutional Courts in Central Europe - Democracy - European Union', $14 E L J(2008)$ p. 1, 6 et seq.

${ }^{11}$ See on that J. Komárek, 'European constitutionalism and the European Arrest Warrant - in Search of the Limits of "Contrapunctual Principles"', 44 CMLRev (2007) p. 9, 16 et seq.; Z. Kühn, 'The European Arrest Warrant, Third Pillar Law and National Constitutional Resistance/Acceptance', 3 CYELP (2007) p. 99 et seq.

${ }^{12}$ French CC, Case 2004-505 DC Constitutional Treaty, decision of 19 Nov. 2004. Cf. the comments of G. Carcassonne, 1 EuConst (2005) p. 293 et seq.; F. Chaltiel, 484 RMC (2005) p. 5 et seq.; X. Magnon, 62 RFDC (2005) p. 329 et seq.; J. Roux, $R D P$ (2005) p. 59 et seq.

${ }^{13}$ French CC, Case 2004-496 DC E-Commerce, decision of 10 June 2004. See the case notes of F.C. Mayer, $E u R$ (2004) p. 925 et seq. (also relating to the decision on the Constitutional Treaty); J. Dutheil de la Rochère, 42 CMLRev (2005) p. 859 et seq.; J.-H. Reestman, 1 EuConst (2005) p. 302 et seq. French CC, Case 2006-540 DC Information Society, decision of 27 July 2006. For comments see F. Chaltiel, RFDC (2006) p. 837 et seq. and C. Charpy, 3 EuConst (2007) p. 436, 445 et seq.

${ }^{14}$ French CE, Case 287110 Ass. Arcelor, decision of 8 Feb. 2007, para. 11. Cf. the case notes of P. Cassia, $R T D E(2007)$ p. 406 et seq.; F. Chaltiel, $R M C$ (2007) p. 335 et seq.; X. Magnon, RFDA (2007) p. 578; A. Levade, RFDA (2007) p. 564, 577; C. Charpy, 3 EuConst (2007) p. 436, 440 et seq. and p. 452 et seq.; F.C. Mayer and E. Lenski and M. Wendel, EuR (2008) p. 63 et seq.

${ }^{15}$ French CE, Case 298348 Mme P, decision of 30 Oct. 2009, para. 9; cf. C. Charpy, 6 EuConst (2010) p. 123 et seq. and C.D. Classen, EuR (2010) p. 557 et seq.

${ }^{16}$ German BVerfG, Case 2 BvR 2661/06 Honeywell, order of 6 July 2010, paras. 58 et seq. The decision was published not until 26 Aug. 2010. An English translation is available at <www.bundesverfassungsgericht.de/en/decisions/rs20100706_2bvr266106en.html>. 
When 'Lisbon' was brought before the courts, it was thus in the context of a highly dynamic evolution of European constitutional law, both at textual and jurisprudential levels. Supreme jurisdictions of several member states - old and new - took Lisbon as an opportunity to add major voices to this jurisprudential choir. It is not exaggerated to claim that the three-year Lisbon saga has become one of the most important cross-border lines of jurisprudence in the history of European constitutionalism, not only in numbers but particularly in terms of substance.

The first decision was issued on 20 December 2007 by the French Conseil constitutionnel, ${ }^{17}$ followed by the order of the Austrian Constitutional Court on 30 September 2008, ${ }^{18}$ the first judgment of the Czech Constitutional Court on 26 November $2008,{ }^{19}$ the judgment of the Latvian Constitutional Court on 7 April 2009, ${ }^{20}$ the judgment of the German Bundesverfassungsgericht on 30 June $2009,{ }^{21}$ the second judgment of the Czech Constitutional Court on 3 November $2009,{ }^{22}$ the judgment of the Hungarian Constitutional Court on 12 June $2010^{23}$ and the second order of the Austrian Constitutional Court the very same day. ${ }^{24}$ The most recent Lisbon decision so far was delivered by the Polish Constitutional Tribunal on 24 November $2010 .{ }^{25}$ Another case is still pending before the Danish

${ }^{17}$ French CC, Case 2007-560 DC Treaty of Lisbon, decision of 20 Dec. 2007.

${ }^{18}$ Austrian CC, Case SV 2/08-3 et al. Treaty of Lisbon I, order of 30 Sept. 2008.

${ }^{19}$ Czech CC, Case Pl ÚS 19/08 Treaty of Lisbon I, judgment of 26 Nov. 2008. An English translation is available at <http://angl.concourt.cz/angl_verze/doc/pl-19-08.php >. See the case note of P. Břiza, 5 EuConst (2009) p. 143 et seq.

${ }^{20}$ Latvian CC, Case 2008-35-01 Treaty of Lisbon, judgment of 7 April 2009. An English translation is available at <www.satv.tiesa.gov.lv/upload/judg_2008_35.htm>.

${ }^{21}$ German BVerfG, Case 2 BvE 2/08 et al. Treaty of Lisbon, judgment of 30 June 2009, BVerfGE 123, 267 et seq. An English translation by the BVerfG (final version) is available at: <www. bverfg.de/entscheidungen/es20090630_2bve000208en.html>. For the multitude of comments compare the 9 pages (sic) of bibliography in the first special issue of $E u R(2010)$ p. 325-333. For mainly critical assessments, see in particular the comments of D. Thym, 46 CMLRev (2009) p. 1795 et seq.; R. Bieber, 5 EuConst (2009) p. 391 et seq.; C. Schönberger, 10 GLJ (2009) p. 1201 et seq.; D. Halberstam and C. Möllers, 10 GLJ (2009) p. 1241 et seq.; C.D. Classen, 64 JZ (2009) p. 881 et seq.; M. Jestaedt, 48 Der Staat (2009) p. 496 et seq.; U. Everling, EuR (2010) p. 91 et seq.; J. Schwarze, EuR (2010) p. 108 et seq.; C. Tomuschat, 70 Zä̈RV(2010) p. 251 et seq.; T. Eijsbouts, 6 EuConst (2010) p. 199 et seq. For more affirmative appraisals cf. F. Schorkopf, 10 GLJ (2009) p. 1219 et seq.; D. Grimm, 5 EuConst (2009) p. 353 et seq.; K.F. Gärditz and C. Hillgruber, 64 JZ (2009) p. 872 et seq.

${ }^{22}$ Czech CC, Case Pl ÚS 29/09 Treaty of Lisbon II, judgment of 3 Nov. 2009. An English translation of the most important sections by J. Komárek is contained in 6 EuConst (2009) p. 345 et seq. For the perspective of a German legal scholar, see I. Ley, 65 JZ (2010) p. 165 et seq.

${ }^{23}$ Hungarian CC, Case 143/2010 (VII. 14.) Treaty of Lisbon, judgment of 12 July 2010. An English translation has not been rendered yet, except for a short press review. For translation and important information I would like to thank warmly Adél Holdampf and Attila Vincze.

${ }^{24}$ Austrian CC, Case SV 1/10-9 Treaty of Lisbon II, order of 12 June 2010.

${ }^{25}$ Polish CT, Case K 32/09 Treaty of Lisbon, judgment of 24 Nov. 2010. 
Supreme Court. ${ }^{26}$ Alongside the decisions of national supreme jurisdictions, there were a number of important advisory opinions and reports, such as the opinion of the Dutch Council of State of 12 September 2007 on the pre-Lisbon IGC mandate, ${ }^{27}$ the opinion of the Danish Ministry of Justice of 4 December $2007^{28}$ and the report of the British House of Lords of 13 March 2008. ${ }^{29}$

Although all of these decisions and opinions paved (or confirmed) the way for ratification in one way or another, they reveal significant differences in procedural as well as in substantial terms. This article will assess the Lisbon jurisprudence from a comparative perspective. ${ }^{30}$ After a brief preliminary reflection about how to compare, the analysis addresses the procedural background and gives a general overview of the decisions. It then tackles the substantial key issues for the future development of EU law which were raised by the decisions, particularly the demands of the supreme jurisdictions regarding democratic legitimacy of EU authority and the courts' claims of constitutional limits and judicial reservations. A concluding remark aims at a question of judicial methodology as the Lisbon decisions reveal a remarkable quality of comparative dialectics between the supreme jurisdictions of the member states.

${ }^{26}$ See on that J.H. Danielsen, 'One of Many National Constraints on European Integration: Section 20 of the Danish Constitution', 16 EPL (2010) p. 181, 190 et seq.

${ }^{27}$ Dutch State Council, Case W02.07.0254/II/E Lisbon-Mandate, opinion of 12 Sept. 2007. An English translation is available at <www.raadvanstate.nl/adviezen>. For a comment, see J. Ziller, 'The Law and Politics of the Ratification of the Lisbon Treaty', in S. Griller and J. Ziller (eds.), The Lisbon Treaty (Springer 2008) p. 309, 319 et seq.

${ }^{28}$ Contrary to what it had said in respect to the Constitutional Treaty, the Danish Ministry of Justice qualified the Lisbon Treaty as a treaty which did not transfer competences in the sense of the constitutional integration clause in the Danish constitution (Art. 20) and thus could be ratified like an ordinary treaty of public international law under Article 19 of the Danish constitution.

29 'The Treaty of Lisbon: an impact assessment', report of 13 March 2008, available at: <www. publications.parliament.uk/pa/ld200708/ldselect/ldeucom/62/62.pdf>.

${ }^{30}$ Apart from the almost uncountable number of comments on the decision of the German BVerfG, there are apparently only three contributions dealing with some of the Lisbon decisions in a comparative perspective, cf. J.-H. Reestman, 'The Franco-German Constitutional Divide', 5 EuConst (2009) p. 374 et seq. specifically concerning the aspect of constitutional identity; A. Weber, 'Die Europäische Union unter Richtervorbehalt', 65 JZ (2010) p. 157 et seq. with a comment on the German Lisbon decision in a broader comparative perspective, and R.U. Krämer, 'Looking through Different Glasses at the Lisbon Treaty: The German Constitutional Court and the Czech Constitutional Court', in A. Fischer-Lescano et al. (eds.) 'The German Constitutional Court's Lisbon Ruling: Legal and Political Science Perspectives', ZERP-Diskussionspapier 1/2010 (Universität Bremen 2010) P. 11 et seq. comparing the first decision of the Czech CC with the Lisbon judgment of the German BVerfG. 


\section{A PRELIMINARY WORD ABOUT COMPARISON}

Comparing must not be cherry-picking. This is why the attempt of a comparative analysis is a challenge in the present context. Some of the judgments under review have almost epic sizes. For instance, the judgment of the German Bundesverfassungsgericht consists of 421 paragraphs, which add up to more than 140 pages in the original print version. These circumstances make it inevitable to focus on the essential lines of argument in order to compare. But how to separate the essential from the nonessential? The particular difficulty here lies not so much in length, but first and foremost in diversity and (deliberate) ambiguity.

Taking the Lisbon judgment of the Bundesverfassunggericht again as example, it is clear that this decision can hardly be described as a monolithic product of judicial reasoning. It is, rather, an expression and reconciliation of a variety of dissonant voices within the German court's Second Senate. ${ }^{31}$ The above-mentioned Honeywell decision is a prime example in this respect. While the majority of the Second Senate establishes remarkable limits to the exercise of ultra vires review, ${ }^{32}$ dissenting judge Herbert Landau holds that the majority hereby 'departs from the consensus on which the Lisbon judgment was based. ${ }^{33}$ It is interesting to see that the merits of the case as well as the dissenting opinion refer basically to the same sections of the Lisbon judgment dealing with the principle of Europarechtsfreundlichkeit (literally 'friendliness towards European law'). ${ }^{34}$ These sections apparently leave enough margin of interpretation for the judges to draw almost antithetic conclusions. If the judges involved cannot agree on the precise content of the consensus on which the Lisbon judgment was based, how should we?

Abstract notions such as the principle of friendliness towards European Law ${ }^{35}$ or the principle of sovereign statehood ${ }^{36}$ become even more problematic when it

${ }^{31}$ An author has aptly compared the resulting multitude of interpretations with the Japanese film 'Rashomon'. All characters have experienced or suffered the same incident, but recount it completely different. See F.C. Mayer, 'Rashomon in Karlsruhe - A Reflection on Democracy and Identity in the European Union', Jean Monnet Working Paper 5/10.

${ }^{32}$ German BVerfG Honeywell, supra n. 16 at para. 58 et seq.

${ }^{33}$ Ibid., para. 102.

${ }^{34}$ The term is translated by the BVerfG as 'openness towards European law'. It must be doubted that this is an appropriate translation as the German term then would have been - semantically even more precise - framed 'Europarechtsoffenheit'.

${ }^{35}$ German BVerfG Treaty of Lisbon, supra n. 21 at para. 225, 240 et seq., and 340. For possible meanings of the concept, see A. Voßkuhle, 'Der europäische Verfassungsgerichtsverbund', $N V w Z$ (2010) p. 1, 5; id., 'Multilevel Cooperation of the European Constitutional Courts', 6 EuConst (2010) p. 175 et seq.; F.C. Mayer, 'Europarechtsfreundlichkeit und Europarechtsskepsis in der Rechtsprechung des Bundesverfassungsgerichts', in T. Giegerich (ed.), Der offene Verfassungsstaat des Grundgesetzes nach 60 Jahren (Duncker \& Humblot 2010) p. 237, 256 et seq.

${ }^{36}$ German BVerfG Treaty of Lisbon, supra n. 21 at para. 224, 228 et seq., 247 et seq., 263, 280 et seq., 299 et seq. 
comes to cross-border comparison. Not only the ambiguities inherent in the concepts themselves, but also the different legal cultures and traditions may cause confusion. ${ }^{37}$ Comparison then runs the risk of getting lost in presuppositions and preconceptions. Picking out an abstract figure of argument contained in judgment $A$ and seeking for possible equivalents in judgment $B$ might end up a comparison of cherries with bananas.

In order to achieve more conclusive results, it is thus reasonable to restrict comparative efforts specifically to those statements which have materialised at least to some degree in the legal outcome. As a consequence, scholarly obiter dicta with generic statements about the nature and finality of the European Union are not central to this comparative review, even though they were written with the intention to have a lasting impact on (academic) debate. ${ }^{38}$ Instead, the following analysis focuses particularly on those sections of the merits that determine the judgments' results.

Even compared in this way, the Lisbon decisions reveal considerable discrepancies. In particular, the varying premises of democratic legitimacy in multi-levelsystems entail varying conclusions regarding the constitutional requirements for the participation of national parliaments. Further, different institutional selfconceptions and normative ideas of sovereignty and (national) identity entail different conceptions of constitutional limits and judicial reservations. But before addressing these substantive questions, let us recall the procedural background of the Lisbon cases and give a general overview over the decisions. Notably, enlightening differences become apparent even following such an examination.

\section{Procedural background and general overview}

Three procedural settings must be distinguished. First, objective treaty reviews before ratification, secondly objective treaty reviews after ratification, and finally individual complaints or petitions being admissible only if the complainant demonstrates an individual encroachment.

\section{Preventive treaty reviews: France and the Czech Republic}

Preventive, i.e., ex ante treaty reviews were carried out in France and the Czech Republic.

\footnotetext{
${ }^{37}$ For the obscurity and polysemy of the term sovereignty in a comparative context, see Wendel, supra n. 4, ch. 3 .

${ }^{38}$ In that sense D. Thym, 'In the Name of Sovereign Statehood', 46 CMLRev (2009) p. 1795, 1821.
} 


\section{France - necessity of a prior constitutional amendment}

The only judicial body which has ruled in substance ${ }^{39}$ both on the Constitutional Treaty as well as on the Lisbon Treaty is the French Conseil Constitutionnel. ${ }^{40}$ In both cases it was asked by the French president to review the compatibility of the respective treaty with the Constitution by means of an objective, ex ante review under Article 54 of the French Constitution.

The two decisions of the Conseil constitutionnel illustrate that the Constitutional Treaty and the Lisbon Treaty are largely congruent. Not in terms of terminology and symbols, as the Dutch Council of State aptly pointed out in its advisory opinion on the IGC mandate $2007,{ }^{41}$ but congruent certainly with regard to their substantial implications on the member state level. In the Lisbon decision the Conseil could thus widely refer $^{42}$ to its previous decision on the Constitutional Treaty in which it had decided that the authorisation to ratify the treaty required a prior revision of the French Constitution. Not surprisingly, neither the binding character of the Charter of Fundamental Rights nor the principle of primacy as enshrined in Article I-6 of the Constitutional Treaty required a constitutional revision. ${ }^{43}$ In this respect the decision of the Conseil was in line with the declaration of the Spanish Constitutional Tribunal, ${ }^{44}$ the advisory opinion of the Belgian Conseil d'Etat ${ }^{45}$ and the report of the Swedish legislative council (lagrådet), which all did not deem a constitutional revision necessary in view of the Constitutional Treaty. ${ }^{46}$

However, the Conseil constitutionnel demanded a prior constitutional amendment for several other reasons: firstly the conferral of certain new competences to the EU, secondly the introduction of supranational modes of decision-making for competences already conferred to the Union, thirdly the introduction of the general bridge clause (now Article 48.7 TEU) and its equivalents in specific fields and,

${ }^{39}$ The Austrian CC has also delivered decisions on both occasions, but rejected all remedies as inadmissible, vide infra.

${ }^{40}$ See the contribution of J. Dutheil de la Rochère, in I. Pernice and J.M. Beneyto Pérez (eds.), Europe's Constitutional Challenges in the Light of the Recent Case Law: Lisbon and Beyond (Nomos 2011 forthcoming).

${ }^{41}$ Dutch State Council Lisbon-Mandate, supra n. 27, point 3.4. See on that J. Ziller, 'The Law and Politics of the Ratification of the Lisbon Treaty', in S. Griller and J. Ziller (eds.), The Lisbon Treaty (Springer 2008) p. 309, 322 et seq.

${ }^{42}$ French CC Treaty of Lisbon, supra n. 17, in particular paras. 12, 21, 24, 26 et seq. and 29.

${ }^{43}$ French CC Constitutional Treaty, supra n. 12 at paras. 13 and 22.

${ }^{44}$ Spanish CT Constitutional Treaty, supra n. 8, in particular points II-4 and II-6.

${ }^{45}$ The advisory opinions are not published. For an analysis cf. F. Delpérée, 'Le Conseil d'Etat de Belgique et le traité établissant une Constitution pour l'Europe', 21 RFDA (2005) p. 242 et seq.

${ }^{46} \mathrm{Cf}$. J. Nergelius, 'Sweden's Possible Ratification of the EU Constitution: A Case-Study of "Wait and See", in A. Albi and J. Ziller (eds.), The European Constitution and National Constitutions ( Kluwer 2007) p. 183, 187. 
last but not least, the new powers given to national parliaments under EU law. ${ }^{47}$ Hence, in the aftermath of both decisions a constitutional amendment had to be passed. ${ }^{48}$ In both cases, these amendments expressly authorised France to participate in the European Union under the conditions laid down in the Constitutional Treaty and the Lisbon Treaty respectively. ${ }^{49}$ Both revisions also aimed at the constitutional authorisation and implementation of the new rights of the French parliament under EU law. ${ }^{50}$ Most of the new provisions were enacted under the condition of the coming into force of the respective treaty. As the ratification of the Constitutional Treaty failed in 2005, the major part of the provisions regarding that Treaty never came into effect, while their successors regarding the Lisbon Treaty only entered into force on 1 December 2009. ${ }^{51}$ The French revision procedure is thus a classic example of the mutual interaction and interdependence of national and supranational constitutional law.

${ }^{47}$ French CC Constitutional Treaty, supra n. 12 at paras. 27 et seq. and later French CC Treaty of Lisbon, supra n. 17, in particular paras. 18 et seq. With regard to parliamentary rights, the CC demanded in its Lisbon decision - in addition to what it had already decided in its previous decision concerning the Constitutional Treaty - a constitutional revision also with regard to the parliamentary veto right under Art. 81.3 TFEU and the subsidiarity control mechanism under the reframed Art. 7.3 of Protocol No. 2 on the exercise of the principles of subsidiarity and proportionality. See paras. 30-32 of the Lisbon decision.

${ }^{48}$ Constitutional Laws No. 2005-204 of 1 March 2005 (with view to the Constitutional Treaty) and No. 2008-103 of 4 Feb. 2008 (with view to the Lisbon Treaty). In addition, the EU related provisions of the French constitution were amended significantly by the constitutional reformpackage contained in Constitutional Law No. 2008-724 of 23 July 2008 which aimed at the 'modernisation of the institutions'. With Art. 61-1 this law also introduced the constitutional basis for the new a posterior review-powers of the French CC (so-called question prioritaire de constitutionnalité).

${ }^{49}$ Art. 88-1. Before the coming into force of the Lisbon Treaty Art. 88-1 contained a separate para. 2 according to which France 'can participate' ('peut participer') in the EU under the conditions laid down in the Constitutional Treaty or the Lisbon treaty (see the respective first article of the Constitutional Laws No. 2005-204 and No. 2008-103).

${ }^{50}$ Cf. Arts. 88-4, 88-6 and 88-7 of the French Constitution. Similar to Art. 23.1a of the German Basic Law, Art. 88-6.3 frames the subsidiarity action as a parliamentary minority right.

${ }^{51}$ With the coming into force of the Lisbon Treaty, the general integration clause in Art. 88-1 was also recast, according to Art. 2 of the constitutional law 2008-103. Art. 88-1 now states that the French Republic 'shall participate in the European Union constituted by States which have freely chosen to exercise some of their powers in common by virtue of the Treaty on European Union and of the Treaty on the Functioning of the European Union, as they result from the treaty signed in Lisbon on 13 Dec. 2007.' 


\section{Czech Republic - two decisions, no amendments}

Like in France, in the Czech Republic the Lisbon Treaty was submitted to ex ante review. ${ }^{52}$ The Czech Senate filed a petition under Article 87.2 of the Czech constitution, introduced in the course of the pre-accession amendment in 2001 in order provide a basis for the preventive review of international treaties. ${ }^{53}$ In its voluminous landmark decision of 26 November 2008 - consisting of 218 paragraphs - the Czech Constitutional Court found the Lisbon treaty to be compatible with the Czech constitutional order. ${ }^{54}$ However, the court limited its scrutiny to those provisions of the Lisbon Treaty expressly contested by the petitioner. ${ }^{55}$

In doing so the Czech Court left the door open for another petition and thus allowed the political opponents of the Lisbon Treaty to initiate a second proceeding. Almost a year after the first decision, on 29 September 2009, a group of Senators filed a second petition which was apparently influenced by the reasoning of the German Lisbon decision. In its second Lisbon judgment of 3 November 2009 the Czech Court decided that the Lisbon Treaty as a whole did not conflict with the Czech constitutional order. ${ }^{56}$ This second judgment is particularly interesting from a comparative perspective as the Czech Court expressly underlined the principle of judicial self restraint and set a clear and articulate contrast to central parts of its German counterpart.

Furthermore, the Czech Court tried to establish limits to a potential procedural abuse of the ex ante treaty review. Referring to obligations under international as well as domestic (constitutional) law, the Court established the requirement to remove doubts on the constitutionality of an international treaty 'without undue delay. ${ }^{157}$ Although it made perfectly clear that the second petition of the Senators, filed about a year later than the first, did not meet this requirement, the Court nevertheless declared the petition admissible in order to avoid 'retroactively burden[ing] the petitioners' with this new interpretation of the relevant procedural rules. ${ }^{58}$ Furthermore, the Court held that the Czech president had an obligation to ratify without undue delay an international treaty duly negotiated by the executive and approved by the democratically elected legislator. It stated

${ }^{52}$ For the decisions of the Czech CC, see the contribution of J. Zemánek, in I. Pernice and J.M. Beneyto Pérez (eds.), Europe's Constitutional Challenges in the Light of the Recent Case Law: Lisbon and Beyond (Nomos 2011 forthcoming).

${ }^{53}$ Constitutional Law No. 395/2001 of 18 Oct. 2001.

${ }^{54}$ Czech CC Treaty of Lisbon I, supra $\mathrm{n} .19$.

55 Albeit including some provisions which were already in force within the framework of the EU- and the EC-treaty, cf. ibid., paras. 75, 77 et seq. and 85-87. See on that P. Bříza, supra n. 19 at p. 145 et seq.

${ }^{56}$ Czech CC Treaty of Lisbon II, supra n. 22.

${ }^{57}$ Ibid., paras. 115 et seq.

${ }^{58}$ Ibid., para. 121. 
that this obligation exists a fortiori when a treaty has been approved with the qualified constitutional majority under the terms of the Czech integration clause (Article 10a). ${ }^{59}$ In other words, when doubts about the constitutionality of an EU treaty arise, only a preventive treaty review initiated within an appropriate period of time can postpone ratification until either a decision of conformity is issued or, in case of conflict, a constitutional amendment is passed. ${ }^{60}$

\section{Ex post treaty reviews: Hungary and Poland}

In Hungary and Poland the Lisbon treaty was reviewed within the framework of an objective ex post review.

\section{Hungary - 'the use of the ex ante review would be desirable'}

In Hungary ratification had been conducted without a prior review of constitutionality. Although this procedure is explicitly provided for, ${ }^{61}$ none of the potential petitioners - neither the Hungarian parliament, nor the president or the government - filed a request. Instead, the Hungarian Constitutional Court decided on the constitutionality of the Act of promulgation of the Lisbon Treaty ${ }^{62}$ within the framework of an ex post review introduced by a person acting in private capacity (actio popularis). ${ }^{63}$ The petition emphasized that the Treaty jeopardized the existence of Hungary as an independent and sovereign state, governed by the rule of law.

While the Hungarian Court declared the petition admissible, it dismissed the case on the merits. ${ }^{64}$ In dealing with the procedural point that the Hungarian ratification had already been completed, the Court underlined that even if the Treaty in question was declared unconstitutional, the adherence to Hungary's legal commitments deriving from EU membership would not be threatened. In that hypothetical situation it would be up to the legislator to find a solution in which the obligations arising under EU law were observed without the violation of the

59 Ibid., para. 116.

${ }^{60}$ Ibid., para. 116.

${ }^{61}$ Under Art. 36.1 of the Act on the Constitutional Court the Hungarian parliament, the president and the government may request the examination of the constitutionality of provisions of the international treaty before its confirmation.

${ }^{62}$ Act CLXVIII of 2007.

${ }^{63}$ According to Art. 1 lit b) of the Act on the Constitutional Court the competence of the Constitutional Court includes i.a. the ex post examination for unconstitutionality of laws.

${ }^{64}$ Hungarian CC Treaty of Lisbon, supra n. 23. Two separate opinions (supporting the over-all result but differing as to the grounds) and a dissenting opinion were delivered with the judgment. While the first separate and the dissenting opinion tackled the question of admissibility in a 'Eurofriendly' way, the second separate opinion highlighted the constitutional limits to the conferral of competences and the principle of primacy. 
Hungarian constitution. ${ }^{65}$ But it did not come to this worst-case scenario as the Court found the Lisbon treaty to be entirely compatible with the constitution. However, it gave the competent political actors a broad hint, that in case of a major reform package like the Lisbon Treaty, the use of the ex ante treaty review would be desirable. ${ }^{66}$

\section{Poland - protest during the oral hearing}

In relation to the use of the preventive treaty review, the situation was similar in Poland. The President of the Polish Republic ratified the Lisbon Treaty on 9 October 2009 without having exercised his power to initiate an ex ante review under Article 133.2 of the Polish Constitution. ${ }^{67}$ The parliamentary statute approving the act of ratification had been adopted pursuant to the procedure of Article 90.2 of the Polish Constitution, which requires an even more demanding majority for the transfer of competences than for a constitutional amendment. ${ }^{68}$ After the ratification had been completed, a group of deputies and a group of senators filed petitions for an ex post treaty review under Article 188 no 1 of the Polish Constitution. ${ }^{69}$

In its judgment of 24 November 2010 the Polish Constitutional Tribunal found the Lisbon Treaty to be compatible with the Polish Constitution. Taking into account that the Polish ratification had been authorised by a qualified legislative procedure and carried out by the president who himself had an obligation to ensure that the Polish Constitution was respected, the Tribunal took the view that the Lisbon Treaty enjoyed a presumption of constitutional conformity which could not be overturned in the present case. Like its Hungarian counterpart, the Constitutional Tribunal had to cope with the procedural particularities of an expost review and found an answer on its own with this line of argument.

In addition, the Polish Lisbon case was characterised by a procedural curiosity. Ultimately, the Constitutional Tribunal decided only in relation to the senators' petition, which was essentially about the constitutionality of the simplified revision

${ }^{65}$ Ibid., point IV.2.

${ }^{66}$ Ibid., point IV.2.2.

${ }^{67}$ According to this provision the president, before ratifying an international agreement may refer it to the CT with a request to adjudicate upon its conformity to the Polish constitution.

${ }^{68}$ Both Arts. 90.2 (parliamentary procedure in case of a conferral of competences to international organisations) and 235.4 (amendment procedure) require a two-thirds majority vote in the chamber of deputies in the presence of at least half of the statutory number of Deputies. The difference is that Art. 90.2 also requires a two-thirds majority vote in the Senate in the presence of at least half of the statutory number of Senators, while Art. 235.4 only requires an absolute majority of votes in the presence of at least half of the statutory number of senators.

${ }^{69}$ This provision establishes the competence of the Polish CT to decide on the conformity of statutes and international agreements with the Polish Constitution. 
procedure, the general regime of Union competences and the flexibility clause under Article 352 TFEU. In contrast, the Tribunal had to drop the case relating to the much more comprehensive petition of the group of deputies. The simple reason for this was that their representative member had left the courtroom in protest during the oral hearing and was therefore regarded as being absent. ${ }^{70}$ However, it is not out of the question that the same group of deputies will make a second effort to bring the case before the Tribunal, including the review of constitutionality of the new accompanying legislation which regulates the cooperation of the Polish government and the parliament in EU affairs.

\section{Individual complaints and petitions: Germany, Austria and Latvia}

While in France, the Czech Republic, Hungary and Poland the constitutionality of the Lisbon treaty was examined within the procedural framework of an objective treaty review, in Austria, Germany and Latvia the proceedings were initiated by individual complaints or petitions which demand the complainant establish (prima facie) a personal interest for review deriving from an individual encroachment, such as the alleged infringement of a fundamental right.

\section{Germany - the right to vote as a catalyst to a full-scale review}

The Lisbon judgment in Germany was predominantly ${ }^{71}$ based on individual constitutional complaints under Article 93.1 no. 4a of the German Basic Law. In 2005 the German Bundesverfassungsgericht had already been confronted with two complaints directed against the act approving the ratification of the Constitutional Treaty. ${ }^{72}$ But after the negative outcome of the referenda in France and the Netherlands and the following period of reflection, the German Court - informally decided not to decide for the time being. The reason given was that it did not want to 'actively contribute' to the discussion about the future of European constitutional development. ${ }^{73}$ It could be argued, however, that the decision not to decide was a political contribution as well, given the context that, at that time, it was more than unclear whether the constitutional reform process would continue.

\footnotetext{
${ }^{70}$ The representative of the group of deputies, deputy Antoni Macierewicz, stormed out of the auditorium after the CT had rejected his motion to postpone the judgment until the bill regulating the cooperation of the government and the parliament in EU affairs came into force. The CT rejected the motion because the initial proceeding covered only the constitutionality of the Lisbon Treaty, but not of the (future) accompanying legislation.

${ }^{71}$ The intra-institutional proceedings initiated by the parliamentary group of the Left Party against the chamber of deputies (Bundestag) were declared inadmissible to a large extent.

${ }^{72}$ Cases 2 BvR 839/05 and 2 BvE 2/05.

${ }^{73}$ This argument was given in a letter by the then judge rapporteur Broß addressed to the parties.
} 
However, that may be, unlike the French Conseil constitutionnel, the Bundesverfassungsgericht thus only delivered a decision on the Lisbon Treaty. Like in the previous Maastricht judgment ${ }^{74}$ the catalyst for admissibility was the right to vote under Article $38 ₫ 1$ of the German Basic Law. The German court construes this right dogmatically as 'equal to a fundamental right' and substantially as

a right to democratic self-determination, to free and equal participation in the state authority exercised in Germany and to compliance with the principle of democracy including the respect of the constituent power of the people. In the present combination of procedural circumstances, the review of a violation of the right to vote also comprises encroachments on the principles which are codified in Article $79 \$ 3$ of the Basic Law as the identity of the constitution. ${ }^{75}$

According to the court, the complainants in the Lisbon case could thus rely on Article $38 \$ 1$ in order to claim a violation of the principle of democracy, the loss of German statehood and 'a violation of the principle of the social state. ${ }^{76}$ The wide interpretation of Article $38 \$ 1$ had already been vividly criticised in the aftermath of the Maastricht judgment ${ }^{77}$ as it enables virtually every German having the right to vote to initiate a de facto objective review of constitutionality, although this specific procedure is only open to an enumerated circle of petitioners under Article $93 \$ 1$ no. 2 of the Basic Law. ${ }^{78}$

What is new in the Lisbon decision is that the Bundesverfassungsgericht connects the right to vote with the constitutional identity as a whole and, furthermore, with the 'respect of the constituent power of the people.' It thus extends its scrutiny in two ways. ${ }^{79}$ First, by invoking Article $38 \$ 1$, a German individual can now claim the violation of theoretically all principles protected by the eternity clause of Article $79 \$ 1$, as far as he or she plausibly demonstrates a 'necessary connection' of these principles with the principle of democracy. ${ }^{80}$ Hence, the German court could not only declare admissible the allegation that the principle of democracy was

${ }^{74}$ German BVerfG, Case 2 BvR 2134 et al. Treaty of Maastricht, judgment of 12 Oct. 1993, BVerfGE p. 89, 155, 171 et seq.

${ }^{75}$ German FCC Treaty of Lisbon, supra n. 21 at para. 208.

${ }^{76} \mathrm{Ibid}$., para. 168. The 'principle of the social state' is part of the basic principles under Art. 20.1 and therefore protected in its material core by Art. 79.3.

77 See already C. Tomuschat, 'Die Europäische Union unter der Aufsicht des Bundesverfassungsgerichts', EuGRZ (1993) p. 489; K.M. Meessen, 'Maastricht nach Karlsruhe', NJW (1994) p. 549, 550 et seq. In the context of the Lisbon judgment, see now R. Bieber, 'An Association of Sovereign States', 5 EuConst (2009) p. 391, 396.

${ }^{78}$ These privileged applicants are: the Federal Government, a Land government, or one fourth (until 30 Nov. 2009 a third) of the members of the Bundestag.

${ }^{79}$ Thym, supra n. 38 at p. 1796 et seq.

${ }^{80}$ German BVerfG Treaty of Lisbon, supra n. 21 at paras. 172 et seq., in particular 182. 
violated, but also that the principle of the social state was encroached upon. ${ }^{81}$ In contrast, it considered the complaints to be inadmissible as far as they were based on an alleged infringement of the rule of law and the separation of powers. ${ }^{82}$

The second extension of the right of scrutiny relates to the pre-constitutional (sic!) concept of the constituent power of the people and thus virtually transcends the legal order of the Basic Law. ${ }^{83}$ According to the Bundesverfassunsgericht, a complainant can rely on Article $38 \$ 1$ in order to challenge the loss of sovereign statehood because the only power with the right to repeal the Basic Law - and with it the German state - is the constituent power of 'the people. ${ }^{84}$ The key idea is that what is exclusively reserved to the pouvoir constituant must not be touched by the pouvoir constitue..$^{85}$ The court held that the 'pre-constitutional right' to give oneself a constitution ${ }^{86}$ is not prescribed but merely declaratively mirrored in Article 146 of the German Basic Law. ${ }^{87}$ To frame it differently, Article $38 \$ 1$ ensures an inner-systemic right of participation within the existing system, while Article 146 reflects an outer-systemic right of participation to create a new system. The logical fracture is that, according to the Bundesverfassungsgericht, the innersystemic voter shall be entitled, by relying on Article $38 \$ 1$, to become the guardian of the outer-systemic constituent power reflected in Article $146 !^{88}$

In brief, the Bundesverfassungsgericht put the right to vote in the centre of its reasoning and thus enabled several claimants, acting in private capacity, to challenge the parliamentary approving act as well as the accompanying laws. Ultimately, the German court found the approving act to be compatible with the constitution. However, it declared the accompanying legislation unconstitutional to the extent that it did not meet the Court's demands for an adequate degree of parliamentary 'responsibility for integration.' The particular quirk of this outcome, unique in Europe, was that the Bundesverfassungsgericht allowed ratification only

${ }^{81}$ Ibid., paras. 168, 181.

${ }^{82}$ The BVerfG took the view that the complainants had not convincingly established a 'necessary connection' with the principle of democracy in this regard, ibid., para. 183.

${ }^{83}$ Critically concerning the pre-constitutional construction also M. Jestaedt, 'Warum in die Ferne schweifen, wenn der Maßstab liegt so nah?', 48 Der Staat (2009) p. 496, 501 and 512 et seq.

${ }^{84}$ For a critique of the BVerfG's concept of 'people', see T. Eijsbouts, 'Wir sind das Volk: Notes about the Notion of "The People" as Occasioned by the Lissabon-Urteil', 6 EuConst (2010) p. 199 et seq.

${ }^{85}$ German BVerfG Treaty of Lisbon, supra n. 21 at para. 179 et seq. and 228.

${ }^{86}$ Can this really be a 'right' in legal categories?

${ }^{87}$ Art. 146 states: This Basic Law, which since the achievement of the unity and freedom of Germany applies to the entire German people, shall cease to apply on the day on which a constitution freely adopted by the German people takes effect.

${ }^{88}$ See German BVerfG Treaty of Lisbon, supra n. 21 at para. 180. See also the critique of D. Halberstam and C. Möllers, 'The German Constitutional Court says "Ja zu Deutschland!", 10 GLJ (2009) p. $1241,1256$. 
under the condition that a new accompanying legislation fulfilling its demands came into force. The German legislator followed the court by enacting a new package of legislation, including the so-called 'Responsibility for Integration Act' (RIA). ${ }^{89}$ After the Bundesverfassungsgericht had declared the remedies directed against these new laws inadmissible, ${ }^{90}$ the package could enter into force and thus paved the way for ratification.

Not every EU citizen has a comparable right to initiate a de facto full-scale review of constitutionality regarding the national ratification procedure. Even an institutionally strong constitutional jurisdiction ${ }^{91}$ is no guarantee that a citizen acting in private capacity may question the ratification procedure by means of an individual complaint.

\section{Austria - total inadmissibility}

The restrictive approach which was taken by the Austrian Constitutional Court illustrates this. In 2005 the Austrian Court had already rejected the remedies against the Constitutional Treaty as inadmissible. In 2008 it proceeded similarly with two individual petitions (Individualanträge) directed against the ratification of the Lisbon Treaty. The petitioners argued in particular that the ratification would amend the basic principles of the Austrian constitutional order in the sense of a 'total revision' and therefore require a national referendum. ${ }^{92}$ By order of 30 September 2008 the Austrian Court denied the admissibility, stating that neither the act of ratification nor the parliamentary resolution authorising it could be challenged. Also the Treaty itself could not, according to the Court, be subject to review as long as it was not in force and therefore not published yet in the Austrian

${ }^{89}$ The RIA is contained in Art. 1 of the new Act Extending and Strengthening the Rights of the Bundestag and the Bundesrat in European Union Matters of 22 Sept. 2009, I no. 60 Official Federal Law Gazette (2009) p. 3022 et seq. The very same day, two other laws were passed, concerning the cooperation between Federal Government and Bundestag in EU matters (I no. 60 Official Federal Law Gazette (2009) p. 3026 et seq.) as well as the cooperation between the Federal state and the Länder in EU matters (I no. 60 Official Federal Law Gazette (2009) p. 3031 et seq.). For a comment, see M. Nettesheim, 'Die Integrationsverantwortung - Vorgaben des BVerfG und gesetzgeberische Umsetzung', 63 NJW (2010) p. 177 et seq.

${ }^{90}$ German BVerfG, Case 2 BvR 2136/09 Accompanying Laws to the Lisbon Treaty, order of 22 Sept. 2009.

${ }^{91}$ For an overview over the 'constitutional' jurisdictions in the EU member states, see F.C. Mayer, 'Multilevel Constitutional Jurisdiction', in A. v. Bogdandy and J. Bast (eds.), Principles of European Constitutional Law, $2^{\text {nd }}$ edn. (Hart 2009) p. 399, 400 et seq.

${ }^{92}$ Under Art. 44.3 of the Austrian Federal Constitutional Law any 'total revision of the Federal Constitution shall ... be submitted to a referendum by the entire nation, whereas any partial revision requires this only if one third of the members of the National Council or the Federal Council so demands.' 
official law gazette. ${ }^{93}$ Hence, in Austria an individual had no legal means of preventively challenging the Lisbon Treaty under the given procedural circumstances, while in Germany individual complainants could attack the parliamentary act approving the Lisbon Treaty before the German ratification was being completed. ${ }^{94}$

By order of 12 June 2010 the Austrian Constitutional Court also finally rejected an individual petition that had been filed after the coming into force of the Lisbon Treaty. This time the petitioner was a group of deputies who had not achieved the necessary majority in parliament to imperatively demand an objective review of constitutionality. ${ }^{95}$ They therefore filed an individual petition. Under Austrian constitutional law such a petition is declared admissible only if the petitioner establishes a prima facie infringement of 'personal rights' that affects him or her 'directly'. The deputies claimed, inter alia, that their constitutional right to participate in a national referendum was infringed and that the conferral of competences to the European Union limited the constitutionally required contribution of the deputies to the exercise of legislative powers as guaranteed in Article 24 (legislative power of parliament) and Article $26 \$ 1$ (right to vote) of the Austrian Federal Constitutional Law. However, the Constitutional Court found that the petitioners did not sufficiently establish that there was an infringement on personal rights affecting them directly. ${ }^{96}$ A comparable criterion of being directly affected is also required for the admissibility of constitutional complaints under German constitutional law. But interestingly, in spite of these similarities, the Austrian Court and the German Bundesverfassungsgericht took a completely different approach.

\section{Latvia - a middle way}

The Latvian Constitutional Court went a middle way between the Austrian solution of total inadmissibility and the German approach of a de facto all-encompassing objective review. Within the framework of a constitutional complaint, ${ }^{97}$ the Latvian Court had to decide if the applicants' fundamental rights under Article 101 of the Latvian constitution were infringed because the ratification of the Lisbon Treaty had - like in Austria - not been submitted to a national referendum. ${ }^{98}$ According to Article 101, every Latvian citizen 'has the right, as provided for by

${ }^{93}$ Austrian CC Treaty of Lisbon I, supra n. 18, point II.2.

${ }^{94}$ German BVerfG Treaty of Lisbon, supra n. 21 at para. 170 in line with established case-law.

${ }^{95}$ The necessary threshold consists of one third of the National Council's (chamber of deputies) members, Art. 140.1 sentence 2 of the Austrian Federal Constitutional Law.

${ }^{96}$ Austrian CC Treaty of Lisbon II, supra n. 24, point II.3.

${ }^{97}$ Cf. Arts. 16 no. $1,17.2$ no. 11 and $19^{2}$ (sic) of the Latvian Act on the Constitutional Court.

${ }^{98}$ Latvian CC Treaty of Lisbon, supra n. 20. 
law, to participate in the work of the State and of local government, and to hold a position in the civil service. (...)'

In its judgment of 7 April 2009, the Latvian Court declared the case admissible on the basis of an alleged violation of Article 101 which, according to the Court, protects the individual right to participate in a referendum as far as the latter is provided for in the constitution or in another normative act. ${ }^{99}$ Two constitutional provisions were claimed to require a national referendum in the present context. The first provision was Article 68.4, according to which 'substantial changes' regarding EU membership shall be decided by a national referendum if at least one-half of the members of parliament so request. The second stipulation was Article 77, which requires a referendum for the amendment of certain fundamental articles, such as the sovereignty-clause in Article $2 .{ }^{100}$ As the Constitutional Court declared the case admissible on the basis of the alleged violation of Article 101 in connection with these two provisions, it consequently limited its scrutiny to the question of whether the Lisbon Treaty had been ratified in compliance with the procedures established in the constitution. ${ }^{101}$ Article 68.4 did not provoke major problems in this respect. Its wording alone indicates that the question whether to submit ratification to a referendum or not lies within the sole hands of parliament. ${ }^{102}$ In contrast, the question of whether the ratification of the Lisbon Treaty touches upon the principle of sovereignty as enshrined in Article 2 and therefore requires a referendum under Article 77, required the Latvian Court to present more detailed reasoning to demonstrate that it did not. ${ }^{103}$

\section{Differences of institutional self-conception?}

To sum up, while in France, the Czech Republic, Hungary and Poland the control of constitutionality was carried out under the procedural rules of objective - ex ante or expost - treaty reviews, the constitutional courts in Germany, Austria and Latvia were confronted with individual complaints or petitions.

Although the Austrian, German and Latvian constitutional courts are all institutionally 'strong' constitutional courts in the classic sense, they came to significantly differing solutions concerning the question of admissibility. While the Austrian Constitutional Court rejected the complaints as entirely inadmissible, the German Bundesverfassungsgericht carried out a de facto full-scale review of

\footnotetext{
${ }^{99}$ Ibid., points 9 and 13 .

${ }^{100}$ Art. 2 reads as follows: 'The sovereign power of the State of Latvia is vested in the people of

${ }^{101}$ Latvian CC Treaty of Lisbon, supra $\mathrm{n} .20$, points 9 et seq.

${ }^{102}$ Ibid., point 19.4

${ }^{103}$ Ibid., points 16.1-18.10. Thus the Latvian CC also rejected a violation of Art. 101.
} Latvia.' 
constitutionality. The Latvian Constitutional Court in turn went a middle way as it affirmed admissibility but limited its scrutiny to specified constitutional grounds for review.

Taking into consideration that the relevant procedural provisions in Austria and Germany share significant similarities, one might ask if the opposing results can be explained by different forms of institutional self-conception or varying degrees of judicial self-confidence. While the Austrian Court sticks closely to the wording of the procedural provisions and thus precludes a private person from preventively challenging the treaty reform, the German Bundesverfassungsgericht creates a de facto preventive treaty review by means of judicial interpretation. Do not be mistaken: The decision of the French Conseil constitutionnel and the obiter dictum of the Hungarian Constitutional Court demonstrate clearly how practical and effective an ex ante treaty review can turn out to be. But the crucial question remains if it is up to a judicial body to create such a procedure if is not foreseen by the constitution or when the procedural conditions for an objective review of constitutionality are not met in the particular case. The approach of the Bundesverfassungsgericht is even more dubitable if one takes into consideration that this court's former competence to deliver advisory opinions was abolished in the early years of the Basic Law. Seen in this light, the Bundesverfassungsgericht's approach of declaring the case admissibility comes close to an act of constitutional 'selfauthorisation'. ${ }^{104}$

\section{LEGITIMIZING THE EU: A CASE OF MULTI-LEVEL DEMOCRACY?}

As all decisions under review paved the way for ratification in one way or another, the substantial key question is their legal impact on the future development of European law and policies. The Lisbon decisions underlined that a decisive factor in this respect is the courts' visions on democratic legitimation of EU public authority. On this point the Lisbon decisions reveal considerable differences.

\section{Parliamentary assent to the future application of 'dynamic treaty provisions'}

The different visions of the national courts on the democratic legitimation of EU public authority become particularly apparent when it comes to the question whether and if so to what extent prior assent of national parliaments is necessary in cases when EU (treaty-) law is developed dynamically, i.e., without an ordinary amendment procedure.

${ }^{104}$ For judicial 'acts of self-authorisation', see - in a historical-comparative perspective D. Herrmann, 'Akte der Selbstautorisierung als Grundstock institutioneller Macht von Verfassungsgerichten', in H. Vorländer (ed.), Die Deutungsmacht der Verfassungsgerichtsbarkeit (VS-Verlag 2006) p. 141,157 et seq. 
Five categories of so-called ${ }^{105}$ 'dynamic treaty provisions' can be distinguished. The first is the simplified treaty revision procedure according to the general clause in Article 48.6 TEU and the specific provisions in Article 42.2 (1) TEU and Articles 25.2, 218.8 (2), 223.1 (2), 262, 311.3 TFEU. The second group is composed of the 'bridge' or 'passerelle' mechanisms enshrined in the general clause of Article 48.7 $\mathrm{TEU}^{106}$ and the specific regimes under Article 31.3 TEU and Articles 81.3 (3), 153.2 (4), 192.2 (2), 312.2 (2), 333.1, 333.2 TFEU. The third category is the flexibility clause in Article 352 TFEU (ex-Article 308 TEC). The fourth case concerns the so-called 'emergency brakes' under Articles 48.2, 82.3 and 83.3 TFEU, which allow for the preliminary suspension of the ordinary legislative procedure if a member state so requests. Finally, the fifth category relates to specific stipulations according to which the Council - after obtaining the consent of the European Parliament - can adopt unanimously decisions in 'sensitive' fields such as criminal law (Article 83.1 (3) TFEU). It is important to note that only the first and the second category concern the simplified (and insofar 'dynamic') amendment of EU treaty law. The other categories relate essentially to the legislative process at EU level. Taking into account the demanding procedural requirements of categories 3-5, one may doubt if the term 'dynamic treaty provisions' as used by the Bundesverfassungsgericht ${ }^{107}$ is an adequate description at all.

\section{Similarities and peculiarities}

The Bundesverfassungsgericht is the only constitutional court in Europe that demands a constitutive authorisation of national parliament in all five cases, ${ }^{108}$ be it by act of parliament or by parliamentary resolution. ${ }^{109}$

As far as the simplified revision procedure under Article 48.6 is concerned, the German court takes a similar approach as the French Conseil constitutionnel, which ruled in both decisions that the ratification of a simplified revision under Article 48.6 TEU requires the authorisation of the French parliament. ${ }^{110}$ In this respect the German court refers explicitly to its French counterpart. ${ }^{11}$

\footnotetext{
${ }^{105}$ Cf. German BVerfG Treaty of Lisbon, supra n. 21 at para. 239.

${ }^{106}$ Cases in which Art. 48.7 could be applied are, for instance, Arts. 82.2 (2) (d), 83.1 (3), 86.4 and 308.3 TFEU.

107 Supra n. 105.

${ }^{108}$ See German BVerfG Treaty of Lisbon, supra n. 21 at paras. 412-419.

${ }^{109}$ For the differences, see in detail I. Pernice, 'Motor or Brake for European Policies? Germany's New Role in the EU after the Lisbon Judgment of Its Federal Constitutional Court', in I. Pernice and J.M. Beneyto Pérez (eds.), Europe's Constitutional Challenges in the Light of the Recent Case Law: Lisbon and Beyond (Nomos 2011 forthcoming), point IV.

${ }^{110}$ French CC Constitutional Treaty, supra n. 12 at para. 36 and later French CC Treaty of Lisbon, supra n. 17, para. 26. According to the CC Art. 53 of the French Constitution applies in this

${ }^{111}$ German BVerfG Treaty of Lisbon, supra $\mathrm{n} .21$ at para. 312 with reference to French CC Treaty of Lisbon, supra n. 17 at para. 26.
} respect. 
But here the parallels between the two judicial bodies end.

As to the application of bridge-clauses, the French Conseil constitutionnel does not demand a prior assent by the French parliament. Instead these clauses are one reason for the Conseil constitutionnel to demand a constitutional amendment for the ratification of the Lisbon Treaty. ${ }^{112}$ The constitutional authorisation which has been introduced in the French constitution in the aftermath of the Lisbon decision (former Article 88-1 \$2) and which allowed the ratification of the Lisbon Treaty thus already encompassed and insofar anticipated all future applications of passerelle-clauses. Therefore the French representative in the Council is entitled to vote for such an application without being previously authorised by parliament to do so. This entails important consequences for the judicial branch as well. As there is no requirement of prior parliamentary assent, the future application of passerelle-clauses cannot be subjected to constitutional review in France. In contrast, in Germany each application of a passerelle-clause can be challenged before the Bundesverfassungsgericht, simply because the authorising parliamentary act can be subjected to constitutional review.

According to the German court, the foundation of the requirement of the parliament's 'positive' involvement is parliament's 'responsibility for integration' - which is in fact also a judicial responsibility. ${ }^{113}$ This applies to all forms of dynamic forms of development mentioned above. ${ }^{114}$

\section{National v. multi-levelled democracy}

The peculiarities of the stance of the Bundesverfassungsgericht become even more apparent if it is contrasted to the Lisbon judgments of the Czech, the Latvian and the Hungarian Constitutional Courts and the Polish Constitutional Tribunal. Like the French Conseil constitutionnel, these courts did not make the ratification of the Lisbon Treaty conditional on the passage of accompanying legislation ensuring the prior assent of national parliaments in the above-mentioned cases. Instead, they highlight that the parliamentary right to veto is a sufficient procedural safeguard. ${ }^{115}$ The Latvian CC ruled that

The TL would introduce additional democratic guarantees, namely, national Parliaments would have the right to object if the EU, based on Article 352 of the TFEU,

${ }^{112}$ French CC Constitutional Treaty, supra $\mathrm{n} .12$ at paras. 33-35 and French ConC Treaty of Lisbon, supra n. 17, paras. 23 et seq. and 27.

${ }^{113}$ See explicitly German BVerfG Treaty of Lisbon, supra n. 21 at para. 236 at the end.

${ }^{114}$ In contrast, particularly Art. 352 TFEU does not seem to be a constitutional problem for the French CC at all.

${ }^{115}$ See Czech CC Treaty of Lisbon I, supra n. 19 at paras. 161-164, 172-175; Czech CC Treaty of Lisbon II, supra n. 22 at para. 134; Latvian CC Treaty of Lisbon, supra n. 20, point 18.6; Hungarian CC Treaty of Lisbon, supra n. 23, point IV.2.5 and Polish CT Treaty of Lisbon, supra n. 25. 
will draft new legal acts. ... Accordingly, the Constitutional Court concludes that Latvia will have the rights and the ability to block changes in the decision-making procedure that are undesirable for Latvia and the Saeima will have the possibility to express its opinion before changes come into force. ${ }^{116}$

The Czech Constitutional Court additionally draws on the jurisprudence of the Court of Justice in order to establish that Article 352 TFEU is not a 'blanket norm' for extending the competences of the Union. ${ }^{117}$ Further, it emphasises the decisive role of the European Parliament, whose consent is not only mandatory under Article 352.1 TFEU but also under Article 48.7(4) TEU. It is precisely in this context that the Czech court in its first Lisbon decision underlines the multi-levelled nature of the democratic legitimation of EU authority. ${ }^{118}$ In their second decision, the Czech judges highlight this point even further. They quote the opinion of former Advocate General Miguel Poiares Maduro regarding the multi-levelled character of the principle of representative democracy ${ }^{119}$ and openly object to the argument of the Bundesverfassunggericht:

Insofar as [Article 10.1] of the TEU provides that "The functioning of the Union shall be founded on representative democracy", that does not mean that only processes at the European level should ensure fulfilment of that principle. That article is directed at processes both on the European and the domestic level, not only at the European Parliament, as stated by the German Constitutional Court in point 280 of its deci$\operatorname{sion}(. .$.$) .$

In other words, the democratic process on the Union and domestic levels mutually supplement and are dependent on each other. (...)

For similar reasons, one cannot see conflict of Article 14.2 of the TEU, which governs the number of members of the European Parliament, with the principle of equality (...). As pointed out above, the European Parliament is not the exclusive source of democratic legitimacy for decisions adopted on the level of the European Union. That is derived from a combination of structures existing both on the domestic and on the European level, and one cannot insist on a requirement of absolute equality among voters in the individual Member States. ${ }^{120}$

${ }^{116}$ Latvian CC Treaty of Lisbon, supra n. 20, point 18.6 (emphasis added).

${ }^{117}$ Czech CC Treaty of Lisbon I, supra n. 19 at para. 151 et seq.

${ }^{118}$ Ibid., para. 173: 'The Treaty of Lisbon transfers powers to bodies that have their own regularly reviewed legitimacy, arising from general elections in the individual member states. Moreover, the Treaty of Lisbon permits several ways of involving domestic parliaments (the possibility for a parliament, or one of its chambers, to directly express its lack of consent, is one of the forms of participation by domestic parliaments)' (emphasis added).

${ }^{119}$ Czech CC Treaty of Lisbon II, supra $\mathrm{n} .22$ at para. 138 with reference to the opinion of former A.G. Poiares Maduro of 26 March 2009, Case C-411/06, Commission v. Parliament and Council.

${ }^{120}$ Ibid., para. 137 et seq. (emphasis added). 
The Czech Constitutional Court thus puts a certain degree of trust in the multilevelled structure of democracy in the European Union and particularly in the ability of the European Parliament to provide for a genuine - albeit not exclusive - link of democratic legitimacy, even despite the EP's degressively proportional composition. In addition, the Czech court highlights the concept of 'pooled' sovereignty. ${ }^{121}$

In contrast, the Bundesverfassungsgericht takes the view that the necessary degree of democratic legitimacy of EU public authority can - at the moment - only derive from the national 'state people' (Staatsvolk). As a consequence, the German court needs to tie the application of the bridging-clauses and the other provisions mentioned above to the prior and constitutive assent of the German parliament. The autonomous democratic mechanisms and institutions on EU-level have, so the argument goes, a complementary character at best, but not a constitutive one.

In so far as the people itself is not directly called upon to decide, democratic legitimation can only be achieved by means of parliamentary responsibility. (...) In so far as the Member States elaborate treaty law in such a way as to allow treaty amendment without a ratification procedure solely or mainly by the institutions of the Union, albeit under the requirement of unanimity, whilst preserving the principle of conferral, a special responsibility is incumbent on the legislative bodies, in addition to the Federal Government, within the context of participation which in Germany, has to comply internally with the requirements under Article 23.1 of the Basic Law (responsibility for integration) and which may be invoked in any proceedings before the Federal Constitutional Court. (...)

Measured against requirements in a constitutional state, even after the entry into force of the Treaty of Lisbon, the European Union lacks a political decision-making body created in equal elections by all citizens of the Union and with the ability to uniformly represent the will of the people. (...) Even in the new wording of Article 14.2 Lisbon TEU, and contrary to the claim that Article 10.1 Lisbon TEU seems to make according to its wording, the European Parliament is not a representative body of a sovereign European people. This is reflected in the fact that it is designed as a representation of peoples in the respective national contingents of Members, not as a representation of Union citizens in unity without differentiation, according to the principle of electoral equality. (...)

The deficit of European public authority that exists when measured against requirements on democracy in states cannot be compensated for by other provisions of the Treaty of Lisbon and, to that extent, it cannot be justified. (...). ${ }^{122}$

If one was asked to trace back the arguments of the Bundesverfassungsgericht to a leading principle, it would neither be sovereignty nor identity, but democracy. The

\footnotetext{
${ }^{121}$ Ibid., para. 147 and Czech CC Treaty of Lisbon I, supra n. 19 at para. 104.

${ }^{122}$ German BVerfG Treaty of Lisbon, supra n. 21 at paras. 236, 280 and 293 (emphasis added).
} 
principle of democracy is the corner stone of the German Lisbon decision. It is the substantial key argument for the German court to declare the case admissible on the basis of an alleged infringement of the right to vote. Moreover, the principle of democracy underlies and even predetermines the principle of sovereign statehood as developed in the Lisbon judgment. ${ }^{123}$ But above all, the principle of democracy is placed at the heart of Germany's constitutional identity, for the right to free and equal participation in public authority is, according to the Bundesverfassungsgericht, 'enshrined in human dignity' itself. ${ }^{124}$

The tragedy is that the Bundesverfassungsgericht's conception of democracy is existentially bound to the (pre-)existence of statehood and is blind to constitutive forms of democratic legitimation within multi-levelled entities. The court thus leaves the Germans with an astonishing binary choice: They may either remain part of the so-called association of sovereign and 'fully democratically' (volldemokratisch) organised states whose 'peoples' remain the only subjects of democratic legitimation. Or they may participate in the creation of a European federal state, which would require a change of the 'subject of democratic legitimation' ${ }^{125}$ and the superseding of one of Germany's most vaunted post-war-inventions: the Basic Law. ${ }^{126}$

If the Germans do not wish to give up their constitution - and who would be surprised if they didn't want to? -, the application of all forms of 'dynamic treaty provisions' must be previously legitimised by the German parliament and remain under the control of the Bundesverfassungsgericht. To frame it differently, as long as the German 'people' does not opt for a European federal state, dynamic treaty mechanisms shall not be too dynamic. Here it becomes clear that the specificities of the Bundesverfassungsgericht's conception of democracy entail direct consequences for the future of European constitutional development.

\section{Who demands prior parliamentary assent: division of powers I}

One might object that the strong critique which is directed against the Bundesverfassungsgericht's Lisbon decision inside and outside Germany, ${ }^{127}$ ignores that Germany is by far not the only country in which prior parliamentary assent is deemed

${ }^{123}$ Ibid., para. 248: 'The safeguarding of sovereignty, demanded by the principle of democracy in the valid constitutional system ...' (emphasis added).

${ }^{124}$ Ibid., para. 211.

${ }^{125}$ The BVerfG demands that democratic requirements in this new entity would have 'to be fully consistent with the requirements for the democratic legitimation of a union of rule organised by a state', cf. ibid., para. 263. However, it is not clear what the normative basis for this claim shall be, as it can't be the (then superseded) Basic Law.

${ }^{126}$ Ibid., paras. 179, 229, 263, 298 and 334. See also D. Halberstam and C. Möllers, supra n. 88 at p. 1255 et seq.

${ }^{127}$ Cf. supra n. 21. 
necessary for the application of dynamic treaty provisions. Examples for such a requirement can also be found in section 6 of the British European Union Amendment Act of $2008^{128}$ (to which the German court refers ${ }^{129}$ ) and in the new Article 23i of the Austrian Federal Constitutional Law, which even requires a qualified majority in both houses of parliament. Also, the Czech legislator in 2009 passed a statute establishing such requirements, not only with respect to the passerelleclauses but also with regard to Article 352 TFEU. ${ }^{130}$

So, much ado about nothing? Not really, because even if such requirements can be found in several member states, the question still remains who took the decision to initiate them. This leads to a second peculiarity. While in Germany it was a court which forced the legislator to establish precisely defined rules to exercise parliamentary responsibility for integration, in all other countries such a decision was taken freely by the (constitutional) legislator. In particular the Czech Constitutional Court left it to the legislative branch to decide how and to what extent national parliaments' rights are to be framed:

However, in this regard we cannot help but see that there are as yet no related provisions in the legal order of the Czech Republic that would allow implementation of the decision making procedures set forth in paragraphs six and seven of Art. 48 on the domestic level. The absence of these procedures, in and of itself, does not affect the question of whether the Treaty of Lisbon is constitutional, but because the Treaty of Lisbon presumes the intervention of domestic parliaments, the government, as the sponsor of the Treaty of Lisbon (...) should reflect that in a timely manner and adequately, by proposing relevant procedures on the domestic level, and should ensure that the Treaty is compatible and interconnected with the constitutional order of the Czech Republic, not only in view of the participation of the parliament, but also in view of the possibility of preliminary review of an amendment of the Treaties by the Constitutional Court. ${ }^{131}$

In other words, the comparative perspective reveals how deeply the German court mistrusts not only the EU political process, but also the political and parliamentary process in Germany. ${ }^{132}$

${ }^{128}$ British European Union (Amendment) Act of 19 June 2008, available at <www.statutelaw. gov.uk/content.aspx?activeTextDocId=3490003>.

${ }^{129}$ German BVerfG Treaty of Lisbon, supra n. 21, at para. 320.

${ }^{130}$ Act No. $162 / 2009$.

${ }^{131}$ Czech CC Treaty of Lisbon I, supra $\mathrm{n} .19$ at para. 165, confirmed in Czech CC Treaty of Lisbon II, supra n. 22 at para. 134.

${ }^{132}$ This is a line of argument which also characterised the European Arrest warrant case. It is probably one of the great ironies that it is a constitutional court which obliges the national parliament to observe its responsibility for integration. 


\section{Popular vote as a requirement for ratification?}

The question of democratic legitimation of EU public authority is of course not limited to the roles of European and national parliaments. It also concerns forms of direct democratic expression.

As seen above, both the Austrian as well as the Latvian Constitutional Courts were being confronted with the question whether the ratification of the Lisbon Treaty required a national referendum or not. ${ }^{133}$ The Latvian court held that a referendum was not mandatory, ${ }^{134}$ while the Austrian court declared the individual petitions inadmissible, laconically repeating its established jurisprudence according to which an individual has only a right to participate in a legally arranged referendum, but not the right to demand such a referendum. ${ }^{135}$ The Bundesverfassungsgericht in turn stated, for the first time, that a (hypothetical) participation of Germany in a federal European state would require a new constitution by referendum under the pre-constitutional right reflected in Article 146.

The only country in which a referendum was held on the Lisbon Treaty was Ireland. ${ }^{136}$ There, the Crotty decision of the Irish Supreme Court (dating back to $1987)^{137}$ initiated a constitutional practice according to which the Irish constitution is supplemented with a specific authorisation for ratification each time a major treaty reform is under way. ${ }^{138}$ As an amendment of the Irish constitution requires a national referendum, ${ }^{139}$ the ratification of every major treaty reform is consequently presumed by a popular vote. ${ }^{140}$

In all other member states a referendum was not deemed necessary, particularly not in France and the Netherlands. In France the decision whether or not to hold a referendum is according to Article 11 of the French constitution a discre-

${ }^{133}$ See also the High Court for England and Wales (Queen's Bench Division, Divisional Court), $R$ (on the application of Stuart Wheeler) v. Prime Minister and Foreign Secretary [2008] EWHC 1409 (Admin), which 'found nothing in the claimant's case to cast doubt on the lawfulness of ratifying the Lisbon Treaty without a referendum' (para. 59).

${ }^{134}$ Latvian CC Treaty of Lisbon, supra n. 20, points 18 and 19.

${ }^{135}$ Austrian CC Treaty of Lisbon II, supra n. 24, point II.3.1.

${ }^{136}$ The first referendum was held on 12 June 2008 and resulted in a negative outcome. The second referendum was held on 2 October 2009 and resulted in a positive outcome. See on that M. Cahill, 'Ireland's Constitutional Amendability and Europe's Constitutional Ambition: the Lisbon Referendum in Context', 9 GLJ (2008) p. 1191 et seq.

${ }^{137}$ Irish Supreme Court, Case 1986 No. 12036P, Crotty v. An Taoiseach [1987] IR 713.

${ }^{138}$ Now Art. 29.4 No. 5 of the Irish constitution. As to the Constitutional Treaty, see G Hogan, 'Ratification of the European Constitution - Implications for Ireland', in A. Albi and J. Ziller (eds.), The European Constitution and National Constitutions (Kluwer 2007) p. 137 et seq.

${ }^{139}$ Art. 46.2 of the Irish constitution.

${ }^{140}$ Whether an express constitutional authorisation is really necessary under the Crotty-doctrine is contentious, see, e.g., A. Maurer and B. Roth, 'Warum Irland abstimmen muss(te) - oder auch nicht', available at <www.swp-berlin.org/common/get_document.php?asset_id=5575>. 
tionary power of the President of the Republic. Unlike his predecessor Jacques Chirac, who put the Constitutional Treaty to a popular vote, ${ }^{141}$ Nicolas Sarkozy opted against a referendum in the case of the Lisbon Treaty.

In the Netherlands the referendum on the Constitutional Treaty was legally speaking purely consultative. ${ }^{142}$ In its opinion on the mandate of the IGC in 2007, the Dutch Council of State underlined that regarding the Lisbon Treaty a consultative referendum was constitutionally admissible, but not required, neither by constitution nor by the mere precedent of the Constitutional Treaty referendum. ${ }^{143}$

In Denmark the decision not to hold on the Lisbon Treaty was preceded by an astonishing opinion of the Ministry of Justice. According to the wording of Article 20 of the Danish constitution, which allows the 'delegation' of competences, a referendum is required only if the specific majority of fifth-sixths of the members of parliament is not achieved. However, in Denmark a constitutional practice has evolved, according to which a referendum is generally held when Article 20 applies, regardless of whether the qualified majority has been met or not. ${ }^{144}$ The Danish Ministry of Justice took the view that, in contrast to the Constitutional Treaty, the Lisbon Treaty would not entail a 'delegation' of competences in the sense of Article 20 and thus would not require a (customary) referendum. ${ }^{145}$ This legal evaluation is neither convincing nor consistent with the Ministry's previous evaluation

${ }^{141}$ The referendum concerning the Constitutional Treaty was appointed by presidential Decree No. 2005-218 of 9 March 2005.

${ }^{142}$ See L.F.M. Besselink, 'Constitutional Referenda in the Netherlands: A Debate in the Margin', 11 EJCL (May 2007) p. 1, 14 and id, 'The Dutch Constitution, the European Constitution and the Referendum in the Netherlands', in A. Albi and J. Ziller (eds.), The European Constitution and National Constitutions (Kluwer 2007) p. 113, 118.

${ }^{143}$ Dutch State Council Lisbon-Mandate, supra n. 27, point 4.2: 'There is nothing in the Constitution to prevent the legislator from holding such referendums on an ad hoc basis, provided that it indicates that there is a special justification for departing from the self-contained arrangements for approving treaties and provided that the referendum procedure is governed by an Act of Parliament. Mere precedent will not suffice. That would create a substantive basis for the referendum as a structural instrument (in this case, for use when approving treaties) which would not be in keeping with the self-contained arrangements in the Constitution.' See on that J. Ziller, 'The Law and Politics of the Ratification of the Lisbon Treaty', in S. Griller and J. Ziller (eds.), The Lisbon Treaty (Springer 2008) p. 309, 317 et seq.

${ }^{144}$ See H. Koch, 'The Danish Constitutional Order', in A.E. Kellermann et al. (ed.), EU-Enlargement - The Constitutional Impact at EU and National Level (TMC Asser Press 2001) p. 109, 111. Critically to this practise H. Rasmussen, 'Denmark's Waning Constitutionalism and Article 20 of the Constitution on Transfer of Sovereignty', in A. Albi and J. Ziller (eds.), The European Constitution and National Constitutions (Kluwer 2007) p. 149, 150.

${ }^{145}$ Opinion of 4 Dec. 2007. In the aftermath of this opinion, on 11 Dec. 2007 the Danish government took the decision to ratify the Lisbon Treaty according to the ordinary procedure under Art. 19 of the Danish constitution. The approval of the Danish parliament followed on 24 April 2008. 
of the Constitutional Treaty. It is clear that the political desire to avoid holding a referendum determined the legal argument.

In summary, the ratification of the Lisbon Treaty shows that in almost all member states a popular vote is not viewed as being constitutionally mandatory for ratification, even in cases of fundamental treaty reform. Instead, in most constitutional orders that allow a consultative or legally binding referendum, the final decision as to whether to hold a referendum rests with the legislative or the executive branch. ${ }^{146}$ With the exception of Ireland, all countries in which a referendum would have been constitutionally possible avoided this for obvious reasons.

\section{CONSTITUTIONAL LIMITS AND JUDICIAL RESERVATIONS}

The supreme jurisdictions also shape future developments of European constitutionalism by establishing constitutional limits and judicial reservations. Here we touch upon the legal consequences of the courts' conceptions of sovereignty and (national) constitutional identity.

\section{Substantive constitutional limits to future developments of EU law}

The first point in this regard aims at substantive constitutional limits to the future development of European Union primary law.

\section{Two categories of constitutional limits}

It is imperative to distinguish two categories of constitutional limits in this respect. On the one hand there are limits that indicate the necessity of a constitutional amendment, on the other hand there are 'red lines' marking the inalienable substantive core of a constitutional order which, in some countries, is not even subject to constitutional revision.

The jurisprudence of the French Conseil constitutionnel provides an example of the first category. According to established case-law, ${ }^{147}$ the Conseil verifies whether the ratification of a new treaty requires a prior constitutional amendment. According to the Conseil, a revision of the French constitution is necessary if the treaty in question contains a clause expressly contrary to the French constitution

\footnotetext{
146 See particularly Arts. 3a.2 of the Slovenian, 68.4 of the Latvian, 90.3 of the Polish and 10a.2 of the Czech constitution, allowing the national parliament to take a decision to substitute or complement its own act of approval by a referendum. In France, according to Art. 88-5 of the constitution any bill authorizing the ratification of a treaty pertaining to the accession of a state to the EU shall be submitted to referendum by the President of the Republic. But also here, by passing a motion adopted in identical terms in each house by a three-fifths majority, parliament may authorize the passing of a bill according to the (parliamentary) constitutional amendment procedure.

${ }^{147}$ See in particular French CC, Case No. 92-308 DC Maastricht I, decision of 9 April 1992.
} 
(1), calls into question constitutionally guaranteed rights and freedoms (2) or affects the 'essential conditions of the exercise of national sovereignty' (3). ${ }^{148}$ The latter is the most important criterion in practice, as the judgments on the Constitutional Treaty and the Lisbon Treaty show. Both treaties jeopardised these 'essential conditions' and thus required a constitutional amendment. Although Article 89.5 of the French constitution sets potential limits to constitutional amendments, ${ }^{149}$ the Conseil constitutionnel has, until today, not relied on this provision in order to establish constitutional limits to European integration. Hence, Article 89.5 does not belong to the relevant norms of reference, neither in the decision on the Constitutional Treaty nor in that on the Lisbon Treaty. Moreover, the Conseil takes the general view that it is not authorised to review constitutional amendments. ${ }^{150}$ The Conseil constitutionnel thus has been described aptly as a pointsman (aiguilleur) which only indicates whether ratification requires amendment of the constitution or not. ${ }^{151} \mathrm{~A}$ further example of the first category is that a constitutional court accepts constitutional limits to the national integra-

${ }^{148}$ Cf. French CC Constitutional Treaty, supra n. 12 at para. 7 and Treaty of Lisbon, supra n. 17, para. 9.

${ }^{149}$ According to Art. 89.5 of the French constitution, the 'republican form of government shall not be the object of any amendment'.

${ }^{150}$ French CC, Case 2003-469 Decentralisation, decision of 26 March 2003, paras. 2 and 3. That the Conseil constitutionnel shows extreme reluctance with regard to Art. 89.5 of the French constitution is also illustrated by its Maastricht decisions. After the Conseil had ruled in a first decision that the ratification of the Maastricht Treaty required a prior constitutional amendment in 1992 (Case 92-308 DC Maastricht I, decision of 9 April 1992) it was asked to review the constitutionality of the Maastricht Treaty a second time. The group of senators who introduced the second proceeding was unsatisfied that the French constituent authority had not amended pre-existing provisions, such as the sovereignty-clause under Art. 3, but had decided merely to supplement the French constitution with several EU related provisions. In other words, the second proceeding would have given the Conseil the opportunity to make its views on the constitutionality of the constitutional amendment. However, the Conseil did not follow the argument of the applicants, according to which the ratification of the Maastricht Treaty was still unconstitutional. Instead it decided that 'subject to the provisions governing the periods in which the Constitution cannot be revised (Arts. 7 and 16 and the fourth paragraph of Art. 89) and to compliance with the fifth paragraph of Art. 89 ('The republican form of government shall not be the object of an amendment'), the constituent authority is sovereign; it has the power to repeal, amend or amplify constitutional provisions in such manner as it sees fit; there is accordingly no objection to insertion in the Constitution of new provisions which derogate from a constitutional rule or principle; the derogation may be express or implied (French CC, Case 92-312 DC Maastricht II, decision of 2 Sept. 1992, para. 19, emphasis added). See on that J. Ziller, 'Sovereignty in France: Getting Rid of the Mal de Bodin', in N. Walker (ed.), Sovereignty in Transition (Hart 2003) p. 261, 271 et seq. In its third Maastricht decision the CC declared itself not competent to decide on the constitutionality of the law approving the ratification as this law had been subjected to a referendum and was thus a direct expression of national sovereignty ('expression directe de la souveraineté nationale'), French CC, Case 92-313 DC Maastricht III, decision of 23 Sept. 1992, para. 2.

${ }^{151}$ L. Favoreu, La politique saisie par le droit (Economica 1988) p. 30. 
tion clause, i.e., the clause allowing the conferral of competencies to the European Union, as long as such limits are not constitutionally inalienable. Examples for such an approach are given by the Lisbon decisions of the Hungarian Constitutional Court ${ }^{152}$ and the Polish Constitutional Tribunal ${ }^{153}$ as regards the integration clauses in both countries.

The most explicit example for the second category is given by the Lisbon judgment of the Bundesverfassungsgericht. As already pointed out, the key argument of this decision is the principle of democracy as protected in its essential content by the so-called 'eternity clause' under Article 79.3 of the German Basic Law. ${ }^{154}$ Hence, the absolute constitutional limits to integration under the German Basic Law begin particularly where the principle of democracy (and with it the right to vote) would be eroded at its substantial core. In the Lisbon judgment the German court identified five key areas within which the future conferral of competencies to the $\mathrm{EU}$ would bear a high risk of violating this material core as protected by the eternity clause:

Particularly sensitive for the ability of a constitutional state to democratically shape itself are [since time immemorial ${ }^{155}$ ] decisions on substantive and formal criminal law (1), on the disposition of the monopoly on the use of force by the police within the state and by the military towards the exterior (2), fundamental fiscal decisions on public revenue and public expenditure, the latter being particularly motivated, inter alia, by social policy considerations (3), decisions on the shaping of living conditions in a social state (4) and decisions of particular cultural importance, for example on family law, the school and education system and on dealing with religious communities (5). ${ }^{156}$

This catalogue is spelled out in more detail in the following paragraphs of the Lisbon judgment. ${ }^{157}$ In a remarkably apodictic way - which has been vividly criticised $^{158}$ - the Bundesverfassungsgericht places constitutional stop signs before

${ }^{152}$ Hungarian CC Treaty of Lisbon, supra n. 23, point IV.2.3.2.

${ }^{153}$ According to the Polish CT Treaty of Lisbon, supra n. 25, this limit is constituted by the key principles determining the 'constitutional identity' of Poland, i.e., the protection of human dignity and the constitutional rights and freedoms, the respect of sovereign statehood and the principles of democracy, the rule of law, social justice and the bases of the economic system.

${ }^{154}$ According to Art. 79.3 of the German Basic Law amendments 'affecting the division of the Federation into Länder, their participation on principle in the legislative process, or the principles laid down in Articles 1 [human dignity - human rights - legally binding force of basic rights] and 20 [constitutional core principles] shall be inadmissible.'

${ }^{155}$ The little, albeit characteristic part 'seit jeher', which suggests historic continuity instead of providing substantial arguments, was left out in the official English translation.

${ }^{156}$ German BVerfG Treaty of Lisbon, supra n. 21 at para. 252.

${ }^{157}$ Ibid., paras. 253-260.

${ }^{158}$ Vf. C. Schönberger, 'Lisbon in Karlsruhe: Maastricht's Epigones at Sea', 10 GLJ (2009) p. 1201, 1208 et seq. who speaks even of an 'arrogation of power'. 
further conferrals of competences. We learn, for instance, that the task of securing the individual's livelihood is and must remain a 'primary task' of the member states. ${ }^{159}$ The only reason why the right to mint and issue coins - which has also been a classical state competence - does not figure in the court's list is probably the mere fact that this marque de souveraineté (Bodin) ${ }^{160}$ has already been conferred to Union level. ${ }^{161}$

\section{Who determines constitutional limits: division of powers II}

From a comparative perspective, it is not striking that a constitutional court derives constitutional limits to European integration from an eternity-clause. But the German Lisbon judgment is exceptional because of the extent to which the Bundesverfassungsgericht relies on Article 79.3. ${ }^{162}$ No other court has spelled out an eternity clause in such a detailed, albeit apodictic manner as the German court did with Article 79.3.

As already mentioned, the French Conseil constitutionnel shows extreme reluctance with regard to Article 89.5 of the French constitution as it acts as a procedural pointsman, leaving the question of whether and of how to amend the constitution to the constitutional legislator. ${ }^{163} \mathrm{~A}$ restrictive approach towards (potential) constitutional eternity clauses can be observed also for Article 139 of the Italian, ${ }^{164}$ Article 110 of the Greek, ${ }^{165}$ Article 288 of the Portuguese, ${ }^{166}$ Article 152.1 and 152.2 of the Romanian ${ }^{167}$ and Article 182 of the Cypriot constitution. ${ }^{168}$

But the peculiarity of the Bundesverfassungsgericht's approach towards the eternity clause - which was drafted primarily in order to prevent a slide back into

${ }^{159}$ German BVerfG Treaty of Lisbon, supra n. 21 at para. 259.

${ }^{160}$ Vf. J. Bodin, Les six livres de la République, $10^{\text {th }}$ edn. (1593 - reprint 1986), book I, chs. XX 295, 306 and 309.

${ }^{161}$ Similarly C. Schönberger, supra n. 155 at p. 1209.

${ }^{162}$ Cf. Weber, supra n. 30, who draws a comparable conclusion.

${ }^{163}$ See, above all, French CC Decentralisation, supra n. 150.

${ }^{164}$ M. Cartabia, 'The Legacy of Sovereignty in Italian Constitutional Debate', in N. Walker (ed.), Sovereignty in Transition (Hart 2003) p. 305, 316.

${ }^{165}$ See J. Iliopoulos-Strangas, 'Offene Staatlichkeit', in A. v. Bogdandy and P.M. Huber (eds.) Ius Publicum Europaeum, vol. II (C.F. Müller 2008) $\$ 16$ Griechenland, para. 43 et seq.

${ }^{166}$ M. Poiares Maduro, 'EU Law and National Constitutions: Portugal', manuscript for BIICL (ed.) FIDE XX Congress London, vol. 1 (BIICL 2002), formerly available at <www.fide2002.org>, p. 13 et seq.

${ }^{167}$ V. Duculescu and A. Ruxandra, 'Romania', in A.E. Kellermann et al. (eds.), The Impact of EU Accession on the Legal Orders of New Member States and (Pre-)Candidate Countries (T.M.C. Asser Press 2006) p. 113, 118 et seq.

${ }^{168}$ For the legal situation in Cyprus, see N. Emiliou, 'Cyprus', in A.E. Kellermann et al. (eds.), The Impact of EU Accession on the Legal Orders of New Member States and (Pre-)Candidate Countries (T.M.C. Asser Press 2006) p. 303, 304 et seq. 
dictatorship ${ }^{169}$ - was expressed most explicitly by the second Lisbon judgment of the Czech Constitutional Court. The Czech judges articulately rejected the petitioners' demand to denominate an abstract catalogue of non-transferrable rights deduced from the Czech eternity clause under Article 9.2 in connection with Article 1.1 of the Czech constitution: ${ }^{170}$

[T] he petitioners ask the Constitutional Court to set 'substantive limits to the transfer of powers', and (...) attempt to formulate these themselves, evidently inspired by the decision of the German Constitutional Court dated 30 June 2009 (...) which provides such a catalogue in point 252 (..).

However, the Constitutional Court does not consider it possible, in view of the position that it holds in the constitutional system of the Czech Republic, to create such a catalogue of non-transferrable powers and authoritatively determine 'substantive limits to the transfer of powers', as the petitioners request. It points out that it already stated [reference to Lisbon I] that 'These limits should be left primarily to the legislature to specify, because this is a priori a political question, which provides the legislature wide discretion' [reference to Lisbon I, para 109]. Responsibility for these political decisions cannot be transferred to the Constitutional Court, it can review them only at the point when they have actually been made on the political level.

For the same reasons, the Constitutional Court does not feel authorised to formulate in advance, in an abstract context, what is the precise content of Article 1.1 of the Constitution, as requested by the petitioners, supported by the president, who welcomes the attempt "in a final list to define the elements of the 'material core' of the constitutional order, or more precisely, of a sovereign democratic state governed by the rule of law" (...).

(...) This does not involve arbitrariness, but, on the contrary, restraint and judicial minimalism, which is perceived as a means of limiting the judicial power in favour of political processes, and which outweighs the requirement of absolute legal certainty (...). The attempt to define the term 'sovereign, unitary and democratic state governed by the rule of law, founded on respect for the rights and freedoms of the man and of citizens' once and for all (as the petitioners, supported by the president, request) would, in contrast, be seen as an expression of judicial activism, which is, incidentally, consistently criticized by certain other political figures. ${ }^{171}$

The reasoning of the Czech court raises questions that go beyond the sole aspect of constitutional limits to European integration as it addresses the more funda-

${ }^{169}$ For the historic background of the German eternity clause, see M. Herdegen, 'Article 79', in T. Maunz and G. Dürig (eds.), Grundgesetz - Kommentar, 59th edn. (loose-leaf) (Beck 2010) paras. 63 et seq.

${ }^{170}$ According to Art. 9.2 of the Czech constitution, the 'substantive requisites of the democratic, law-abiding State may not be amended.' According to Art. 1.1, the 'Czech Republic is a sovereign, unitary and democratic, law-abiding State, based on respect for the rights and freedoms of man and citizen.'

${ }^{171}$ Czech CC Treaty of Lisbon II, supra n. 22 at paras. 110-113 (emphasis added). 
mental question regarding the relationship between law and the political. To frame it differently, at the heart of its reasoning, the Czech court raises the question of institutional choice in the sense of to what extent a court should (re-)write the constitution by means of interpretation and where it should leave the decision to the legislator. The answer given is clearly in favour of the political process. Does the second Lisbon judgment of the Czech court bear the hand-writing of those authors who had underlined the limits of judicial reasoning on earlier occasions, particularly within the context of the European Arrest Warrant? ${ }^{172}$

Anyway, as regards the determination of constitutional limits to further steps of European integration, the comparative analysis reveals that the Conseil constitutionnel and the Czech Constitutional Court throw the ball back into the political arena. ${ }^{173}$ In contrast, the Bundesverfassungsgericht claims to be competent to determine limits to European integration which can only be overcome by superseding the German Basic Law. While the Conseil constitutionnel and the Czech Constitutional Court stay within the existing constitutional system by referring to the legislator or the constituent authority, the Bundesverfassungsgericht tends to transcend the constitutional order (by which it is itself constituted) when it refers to a pre-constitutional right to give oneself a constitution. ${ }^{174}$

\section{Challenges to the applicability of EU law}

Alongside the manifestation of substantial constitutional limits to future developments of EU (primary) law, the Lisbon decisions also address challenges to the applicability of EU law in force. Some of the courts particularly highlight their review power in cases of alleged ultra vires acts and violations of the so-called national constitutional identity.

\section{Ultra vires review}

As far as national constitutional courts claim to be competent for ultra vires review - that is to review if an act of EU law has transgressed the Union's competences and to declare it inapplicable in case it does ${ }^{175}$ - the courts agree in principle that restrictive conditions must apply to its exercise.

\footnotetext{
${ }^{172}$ See in particular J. Komárek, supra n. 11 at p. 38 et seq. within the context of the European Arrest Warrant cases.

${ }^{173}$ This does not mean, however, that the Czech CC would pass the buck to the legislator in all cases. But it holds that the 'interference by the Constitutional Court should come into consideration as ultima ratio' only, see Czech CC Treaty of Lisbon I, supra n. 19 at para. 109.

${ }^{174}$ See again German BVerfG Treaty of Lisbon, supra n. 21, para. 179.

175 'Ultra vires act' is here understood in the narrower sense of the word, in contrast to the wider concept which covers also infringements of other principles of EU law than only the principle
} 
In the Lisbon judgment, the Bundesverfassungsgericht refined its previously developed ${ }^{176}$ concept of ultra vires review on several crucial points. ${ }^{177}$ The court underlined that the decision to declare an act of EU law inapplicable within the framework of an ultra vires review is reserved to the constitutional court alone. ${ }^{178}$ In a surprising obiter dictum, the court even proposed to the legislator to introduce a new proceeding before the court 'tailor made' for this kind of review. ${ }^{179}$ But the most important novelty was substantive: that the court limited ultra vires review to 'obvious transgressions' and to cases where 'legal protection cannot be obtained' at EU level. ${ }^{180}$

In its Honeywell decision of 6 July 2010, the Bundesverfassungsgericht confirmed this restrictive approach, albeit at the cost of having a dissenting opinion. The case dealt essentially with the question of whether the German Federal Labour Court could lawfully align its jurisprudence with the Mangold judgment of the Court of Justice. ${ }^{181}$ According to the Bundesverfassungsgericht, ultra vires review requires a prior reference to the Court of Justice in terms of procedure. ${ }^{182}$ In terms of substance, an act of Union law may only be declared inapplicable if the breach of competences is 'sufficiently qualified'. The fulfilment of this criterion depends on a double test which will produce affirmative results only in very exceptional, not to say hypothetical circumstances. Firstly, the act in question must constitute an evident violation of competences. Secondly, the impugned act must entail a significant impact on the system of distribution of competences between the member states and the Union to the detriment of the former. In brief, the violation must be obvious and simultaneously change structurally the division of competences between the Union and the member states. ${ }^{183}$

Concerning possible ultra vires acts committed by the judicial branch and the Court of Justice in particular, the Bundesverfassungsgericht affirmed in Honeywell the 'respect for the Union's own methods of justice' and even highlighted that the

of conferral, such as the fundamental rights for example. For the different notions, see F.C. Mayer, Kompetenzüberschreitung und Letztentscheidung (C.H. Beck 2000) p. 24 et seq.

${ }^{176}$ German BVerfG Maastricht, supra n. 74 at p. 187 et seq. The claim to exercise an ultra vires review could already be identified previously in Case 2 BvR 255/69 Lütticke, order of 9 June 1971, BVerfGE 31, 145, 174 and Case 2 BvR 687/85 Kloppenburg, order of 8 April 1987, BVerfGE 75, $223,235$.

177 This cannot be dealt with in detail here.

${ }^{178}$ Ibid., para. 241.

${ }^{179}$ At the moment there is no political majority which would opt in favour of such a solution, which might even, for good reasons, give impetus to an infringement procedure under Art. 258 TFEU (ex-Art. 226 TEC).

${ }^{180}$ German BVerfG Treaty of Lisbon, supra n. 21 at para. 240.

${ }^{181}$ ECJ, Case C-144/04 Mangold, judgment of 22 Nov. 2005.

${ }^{182}$ German BVerfG Honeywell, supra n. 16 at para. 60.

${ }^{183}$ Ibid., Para 61. 
Court of Justice had a 'right to tolerance of error. ${ }^{\text {,184 }}$ The question of whether the Court of Justice transgressed the Union's competences in its famous Mangold judgment, was expressly left open by the German court, ${ }^{185}$ as it took the view that, in any case, the second requirement of the double test was not fulfilled: 'neither a new field of competences was created for the Union to the detriment of the Member States, nor was an existing competence expanded with the weight of a new establishment.'

This restrictive approach should, however, not overshadow the fact that the Honeywell case marks the first time that a national constitutional court actually undertook an ultra vires review, ${ }^{186}$ even if the German court rejected the constitutional complaint as unfounded.

The ultra vires claim is a prominent example for cross-border migration ${ }^{187}$ of constitutional ideas. Originally developed by the Bundesverfassungsgericht, it was taken up by the Danish Highest Court in its Maastricht decision, ${ }^{188}$ the Polish Constitutional Tribunal in its decision on the Accession Treaty ${ }^{189}$ and also the Czech Constitutional Court in its Lisbon decisions. ${ }^{190}$ The Polish and the Czech decisions even drew explicitly on the German Maastricht decision for inspiration. ${ }^{191}$

Although not being equally sophisticated in terms of dogmatics, the jurisprudence of the Danish and the Czech courts principally correspond to the restrictive course of the Bundesverfassungsgericht. Both courts underline that ultra vires review must be exercised only in exceptional circumstances. ${ }^{192}$ A similar conclusion can

${ }^{184}$ German BVerfG Honeywell, supra n. 16 at para. 66.

${ }^{185}$ The question was whether the ECJ could derive a 'general principle of the prohibition of discrimination based on age' from the constitutional traditions common to the Member States and from their international agreements.

${ }^{186}$ One could have interpreted as early as the Kloppenburg decision - supra n. 176 - in that way.

${ }^{187}$ For the concept cf. S. Choudhry, 'Migration as a new metaphor in comparative constitutional law', in id. (ed.), The Migration of Constitutional Ideas (CUP 2006) p. 1 et seq.

${ }^{188}$ Danish HC, Case I 361/1997 Carlsen v. Rasmussen, judgment of 6 April 1998.

${ }^{189}$ Polish CT Accession Treaty, supra n. 9 at points 10.3 and 4.5.

${ }^{190}$ Czech CC Treaty of Lisbon I, supra $\mathrm{n} .19$ at paras. 120, 139 and 216; Treaty of Lisbon II, supra n. 22 at para. 150 referring to the first decision.

${ }^{191}$ This expression is used by the Czech CC in its first Lisbon decision, supra n. 19 at para. 111. The Czech CC regularly refers to other constitutional courts. One of the most striking examples in this respect is its second sugar quota case of 2006 in which it quotes the assembled prominence of European landmark decisions relating to the principle of primacy, see Czech CC, Case Pl ÚS 50/04 sugar quotas II, decision of 8 March 2006, point VI.A.

${ }^{192}$ Cf. supra n. 188 and n. 190. 
be deduced from the jurisprudence of the Polish Constitutional Tribunal, ${ }^{193}$ even despite some rhetorical differences. ${ }^{194}$

In brief, the Lisbon jurisprudence and subsequent cases confirm that the constitutional courts which claim to be competent for ultra vires review construe it as an exceptional review of last resort.

\section{Identity review}

The picture is more heterogeneous in relation to claims to review whether an act of EU law violates the national constitutional identity. This begins with the term 'identity'. Whereas the concept of 'ultra vires act' can be defined in a relatively clear manner, the notion of identity remains obscure. ${ }^{195}$ But although (or just because?) it runs risk of drifting away in the cloudy spheres of nebulosity, it nevertheless seems to have the potential of becoming a universal term ${ }^{196}$ of European constitutional law.

The notion of 'constitutional identity' is used by several national supreme jurisdictions as a synonym for constitutional core principles protected against the primacy of EU law. ${ }^{197}$ While this alone is hardly revolutionary, ${ }^{198}$ the concept of constitutional identity has recently turned out to be a genuine phenomenon of multilevel-constitutionalism. Some of the courts no longer rely exclusively on national constitutional law, but also on the new framed identity-clause in EU law (Article 4.2 TEU) in order to justify the protection of the said core principles.

The first decision interesting in this respect is the declaration of the Spanish Constitutional Tribunal on the Constitutional Treaty. For the Spanish Tribunal,

${ }^{193}$ In that sense also S. Biernat, supra n. 9 at para. 46.

${ }^{194}$ The Czech CC distances itself expressly from the Polish CT: 'The Polish Constitutional Tribunal, for example, expressly rules out the jurisdiction of the Court of Justice to evaluate the limits of conferral of competences on the EU, as, according to the Tribunal, that is a question of interpretation of domestic constitutional law. Although, in terms of the dogmatics of domestic constitutional law, we can agree with that conclusion to a certain extent, it is questionable whether it is necessary to formulate it as sharply as the Tribunal did' (Czech CC Treaty of Lisbon, supra n. 19 at para. 139).

${ }^{195}$ See J.-H. Reestman, supra n. 30 at p. 374 et seq. and A. v. Bogdandy, 'Europäische und nationale Identität: Integration durch Verfassungsrecht?’, 62 VVDStRL (2003) p. 156 and 164.

${ }^{196}$ For the concept of universal terms in a judicial context, see M. Poiares Maduro, 'Contrapunctual Law'm in N. Walker (ed.), Sovereignty in Transition (Hart 2003) p. 501, 527 et seq.

197 See also F.C. Mayer, supra n. 31, 36.

${ }^{198}$ For the use of the term 'identity' within the context of constitutional core principles, see already German BVerfG, Case BvL 52/71 Solange I, order of 29 May 1974, BVerfGE 37, 271, 279 et seq. and Case 2 BvR 197/83 Solange II, order of 22 Oct. 1986, BVerfGE 73, 339, 375 f with reference to the jurisprudence of the Italian CC (in particular Italian CC, Case 183/73 Frontini, decision of 18 Dec. 1973) which does not use the term, but follows a comparable approach in substance. 
the identity clause (formerly planned as Article I-5 of the Constitutional Treaty) is one of the key arguments to assume that an act of EU law which violates the fundamental principles of the Spanish constitution would automatically also constitute an infringement of European Union law and would therefore be sanctioned already by Union law itself. ${ }^{199}$ To frame it differently, the Spanish Tribunal sees the identity-clause as one of several 'inbuilt breaks' of the Treaties which ensure that the Tribunal will never get into the position to have to declare an act of EU law inapplicable in Spain, because before it reaches the Tribunal the infringement will already have been sanctioned on the Union level. ${ }^{200}$ This is why the Spanish Constitutional Tribunal can refer its own review power into the realm of the hypothetical.

The identity-clause is also highlighted by the French Conseil constitutionnel in its decision on the Constitutional Treaty. The Conseil concluded from a combined reading of the (formerly planned) primacy clause and the identity clause that the principle of primacy is, on the one hand, acknowledged, but, on the other hand, also potentially limited. According to the Conseil, the Constitutional Treaty, and

particularly the close proximity of Articles 1-5 and 1-6 thereof, show that it in no way modifies the nature of the European Union, nor the scope of the principle of the primacy of Union law as duly acknowledged by Article 88-1 of the Constitution, and confirmed by the Constitutional Council in its decisions. ${ }^{201}$

Among the jurisprudence referred to, a decision stands out in which the Conseil constitutionnel stated that the obligation to transpose a directive follows not only from EU law but also from French constitutional law (Article 88-1) and nontransposition would only be possible on the grounds of an expressly contrary provision of the French constitution. ${ }^{202}$ This constitutional entrenchment of the obligation to transpose a directive allows the Conseil to sanction the enforcement of EU law by means of French constitutional law and simultaneously to limit this obligation by colliding constitutional provisions. In a decision of 2006 the Conseil constitutionnel specified these potential limits as those regarding French 'constitutional identity'. According to the Conseil constitutionnel, the 'the transposition of

${ }^{199}$ Spanish CT Constitutional Treaty, supra n. 8, point II-3. In this sense, see the case note of F. Castillo de la Torre, 42 CMLR (2005) p. 1169, 1195 et seq. and A.C. Becker, 'Vorrang versus Vorherrschaft', EuR (2005) p. 353, 355.

${ }^{200}$ Cf. F. Castillo de la Torre, 42 CMLR (2005) p. 1169, 1193 and 1201.

${ }^{201}$ French CC Constitutional Treaty, supra n. 12 at para. 13.

${ }^{202}$ French CC E-Commerce, supra n. 13 at para 7. See also Case No. 2004-498 DC Bioethics, decision of 29 July 2004, para 4. This reasoning has been aptly described as a legal osmosis, cf. F. Chaltiel, 'Constitution française, constitution européenne, vers l'osmose des ordres juridiques?', $488 R M C(2005)$ p. 280 et seq. 
a Directive cannot run counter to a rule or principle inherent to the constitutional identity of France, except when the constituting power consents hereto.'203

While it is not clear what exactly falls under the 'constitutional identity' of France - one could argue that this concept covers only those principles specific to the French constitutional order, such as the principle of secularism $-{ }^{204}$ it is definite that the constitutional identity in the jurisprudence of the Conseil constitutionnel does not constitute an inalienable limit to European integration. Instead, the final decision whether or not infringement of French constitutional identity should be allowed rests with the constituting power.

There are several differences between the approach of the French Conseil constitutionnel and the German Bundesverfassungsgericht as regards the concept of constitutional identity. ${ }^{205}$ But the most important is the following. While in Germany the Bundesverfassungsgericht grants the constitutional identity absolute protection under the eternity clause, in France the constituent authority maintains the right to adapt the French constitution. If the French Conseil constitutionnel ever held that the implementation of a directive would infringe the constitutional identity of France, then the constitution could be revised.

In Germany, on the contrary, the notion of constitutional identity is bound to Article 79.3 of the Basic Law, which shields the substantial core of the constitution even against a revision. On this basis the Bundesverfassungsgericht claims to be competent to review whether an act of EU law infringes Germany's constitutional identity and is thus inapplicable within Germany. The court holds that otherwise

the fundamental political and constitutional structures of sovereign Member States, which are recognised by Article 4.2 first sentence Lisbon TEU, cannot be safeguarded in any other way. In this respect, the guarantee of national constitutional identity under constitutional and under Union law go hand in hand in the European legal area. The identity review makes it possible to examine whether due to the action of European institutions, the principles ... declared inviolable in Article 79.3 of the Basic Law, have been violated. This ensures that the primacy of application of Union law only applies by virtue and in the context of the constitutional empowerment that continues in effect. ${ }^{206}$

${ }^{203}$ French CC Information Society, supra n. 13 at para. 19.

${ }^{204} \mathrm{Cf}$. in that sense the conclusions of the former rapporteur public at the French Conseil d'Etat M Guyomar in case Arcelor, RTDE (2007) p. 378, 385.

${ }^{205}$ This cannot be dealt with in detail here. For details, see the brilliant analysis of J.-H. Reestman, supra n. 29 at p. 384 et seq., particularly p. 388-390.

${ }^{206}$ German BVerfG Treaty of Lisbon, supra n. 21 at para. 240 (emphasis added). 
The picture of 'hand in hand' is deceiving. It alludes to mutual loyalty, which would indeed make sense as the new identity clause is placed directly alongside the principle of mutual loyalty enshrined in Article 4.3 TEU. However, as to the legal consequences of the Bundesverfassungsgericht's approach, the metaphor of 'pulling and tearing' would be more adequate. The German court construes the identity clause as a mere reflex or fingerprint of (national) sovereign statehood. In other words, Article 4.2 TEU is seen as a declarative affirmation of the Bundesverfassungsgericht's alleged right to decide unilaterally on the inapplicability of EU law within Germany. Once the constitutional identity is touched, the game is over. Even if the German court underlines that the exercise of this review power must be reconciled with the constitutional principle of 'friendliness towards European Law $^{207}$ and seems to indicate in its Honeywell decision that the restrictive procedural requirements set up for the ultra vires review might also apply for the identity review, ${ }^{208}$ one must strongly doubt that the Bundesverfassungsgericht's approach corresponds to an adequate understanding of Article 4.2 TEU.

First, according to the Bundesverfassungsgericht's conception, everything depends on the content or non-content of the term identity. Is it now possible to circumvent the Solange II decision and the Banana decision ${ }^{209}$ by claiming that the essential core of a fundamental right - protected as part of the constitutional identity - has been violated? ? $^{210}$ If so, the reference to the identity-clause might constitute opening Pandora's box. ${ }^{211}$

Second, even if the German Lisbon judgment does not re-open the Solange saga, ${ }^{212}$ its approach remains, again, blind to the multi-levelled structure of European constitutionalism. If it is true that the identity-clause aims at the protection of specificities and core principles of national constitutions, then EU law cannot determine what 'constitutional identity' is. To that extent Article 4.2 TEU is open to varying evaluations of national authorities, including national courts. But the

${ }^{207} \mathrm{Ibid}$.

${ }^{208}$ German BVerfG Honeywell, supra n. 16 at para. 59: 'According to the legal system of the Federal Republic of Germany, the primacy of application of Union law is to be recognised and it is to be guaranteed that the control powers which are constitutionally reserved for the Federal Constitutional Court are only exercised in a manner that is reserved and open towards European law.'

${ }^{209}$ German BVerfG, Case 2 BvL 1/97 Banana-Market, order of 7 June 2000, BVerfGE 102, 147 et seq.

${ }^{210}$ In Case 1 BvR 256/08 et al. Data retention, judgment of 2 March 2010, para. 218 the German BVerfG stated: 'It is part of the constitutional identity of the Federal Republic of Germany that the citizens' enjoyment of freedom may not be totally recorded and registered, and the Federal Republic must endeavour to preserve this in European and international connections.' The BVerfG here referred explicitly to the identity control under para. 240 of the Lisbon judgment. In its Lisbon judgment the BVerfG also identified the principle of nulla poena sine culpa as being an integral part of the German constitutional identity, German BVerfG Treaty of Lisbon, supra n. 21 at para. 364.

${ }^{211}$ See Mayer, supra n. 31, 39 et seq. concluding that in some way any problem of protection of fundamental rights could thus be treated as a problem of constitutional identity too.

${ }^{212}$ In this sense Thym, supra n. 38 at p. 1807. 
question of content must be separated from the question of normative relevance. Even if Article 4.2 TEU is an auto-limitative response of EU law to the claims of national jurisdictions that certain core principles of national constitutions are not subject to the principle of primacy, then the question of how far EU law limits its own claim of primacy still remains a question of EU law. This is a logical consequence of the formal separation of national and supranational law. Consequently the extent to which the identity claim is normatively relevant within the realm of EU law is a question to be decided by EU law and thus by the Court of Justice. In other words, according to our interpretation, while national constitutional courts may decide on the content of constitutional identity, the Court of Justice decides if and to what extent the identity claim prevails over (hypothetically) conflicting principles of EU law.

Seen in this way, Article 4.2 appears as an integration clause on Union-level ensuring the legal permeability of EU law with regard to national constitutional law. ${ }^{213}$ By means of the identity clause, EU law revokes to some extent - and not unlimited - its own claim of primacy within its scope of application. Hence, the task of protecting national constitutional identity is, under EU law, not a task reserved for national courts. It is instead distributed between supranational and national level.

In this respect it is important to note that Article 4.2 contains, according to its wording, an obligation for the EU to 'respect' the member states' national identity, not to generally outweigh other principles of EU law against it. Otherwise, we would be back to Pandora's box. ${ }^{214}$ The deliberations of the European Convention confirm the view that the identity clause is not framed as a unilateral 'derogation clause' on which the Court of Justice ${ }^{215}$ not be competent to rule. ${ }^{216}$ The role of the Court of Justice as a 'first line of defence' seems to be presumed also by the Spanish Constitutional Tribunal in its declaration on the Constitutional Treaty as far as it assumes that a violation of the core principles of the Spanish constitution would not occur, because such a violation would simultaneously constitute an infringement of EU law sanctioned by the Court of Justice. ${ }^{217}$

${ }^{213}$ In legal terms, permeability can be defined as the capacity of a given legal order to limit its own claim of normative exclusivity in order to enable legal rules or principles which emanate from a formally separated legal order to integrate. See in detail Wendel, supra n. 3, chs. 1 and 13.

${ }^{214}$ See also A.G. M. Poiares Maduro, Case C-213/07 Michaniki, opinion of 28 Oct. 2008, para. 32 et seq.

${ }^{215}$ The ECJ was, under the former Art. 46 of the TEU-Nice, not competent to interpret the identity-clause under the former Art. 6.3 TEU-Nice.

${ }^{216} \mathrm{CONV} 375 / 1 / 02 \mathrm{REV} 1$, p. 11: 'In the latter respect it was noted that the provision was not a derogation clause. The Member States will remain under a duty to respect the provisions of the Treaties. ... Were the Court of Justice to be given power with respect to such article in a future "basic treaty of constitutional significance", the Court could be the ultimate interpreter of the provision if the political institutions went beyond a reasonable margin of appreciation.'

${ }^{217}$ See also F. Castillo de la Torre, 42 CMLR (2005) p. 1169, 1201. 
However, once the protection of constitutional identity has been identified as a genuine task of multi-level constitutionalism in which the preliminary reference procedure assures the necessary dialogue between the Court of Justice and the national courts, the question arises of whether the Court of Justice has taken up its mission so far. Is the Court of Justice really capable of a multi-level conception of the identity clause? This premise would at least entail the Court of Justice handling the identity clause as a justiciable provision of EU law, now that the Court of Justice is legally competent to interpret it. ${ }^{218}$ However, even if the AdvocatesGeneral have brought up the question of constitutional identity regularly before the Court of Justice in recent times, ${ }^{219}$ the Court of Justice remains silent about the possible impact of Article 4.2 TEU and thus risks of handing over the reins to the national courts. ${ }^{220}$

\section{CONClusion: A NEW QUALITY OF COMPARATIVE DIALECTICS}

To conclude, the Lisbon decisions reveal significant differences not only in terms of procedure, but first and foremost in terms of substance. While the German Bundesverfassungsgericht's Maastricht decision became an often quoted leading case in cross-border perspective, it is unlikely that its Lisbon judgment will have a similar effect.

The comparative analysis reveals instead that the Bundesverfassungsgericht is the only constitutional court in Europe which - based on a conception of democracy bound existentially to statehood - demands a prior constitutive assent of national parliament in all possible cases of so-called dynamic treaty provisions. The Bundesverfassungsgericht is also the sole court to declare itself competent to spell out a constitutional eternity clause in a detailed (albeit apodictic) manner, enlisting whole areas within which the future conferral of competencies to the EU could bear a high risk of violating national constitutional identity.

But beyond the mere fact of apparent differences, the Lisbon judgments reveal a new quality of judicial dialogue and comparative exchange of national courts. Indeed, it is not a new phenomenon that national constitutional courts stay in close, albeit informal, contact ${ }^{221}$ and refer to each other sporadically in their decisions. ${ }^{222}$ But in the Lisbon saga, the frequency of such cross-references is rather

${ }^{218}$ Cf. supra n. 215.

${ }^{219}$ See particularly the opinion of A.G. M. Poiares Maduro in the case Michaniki, supra n. 213 at para. 32. For more examples, see Wendel, supra n. 3, ch. 13 point II-2-a.

${ }^{220}$ An example how the protection of constitutional identity might work in practice is the Omega-case, ECJ case C-36/02 Omega, judgment of 14 Oct. 2004. However, the term 'identity' is not used within this decision.

${ }^{221}$ Cf. for example the Conference of European Constitutional Courts, <www.lrkt.lt/confer ence 5.html>.

${ }^{222}$ Cf. supra n. 198. 
high. References can be found chronologically in the decisions of the Czech Constitutional Court, the German Bundesverfassungsgericht, the Hungarian Constitutional Court and the Polish Constitutional Tribunal. Most of these references are punctual affirmations used to support a specific argument as far as it is congruent with the approach taken by another court. These references do not imply that the judgments referred to serve as a normative basis, but rather reflect a comparative 'inspiration' as the Czech Constitutional Court has called it. The possibility of being inspired in this way is increased by the fact that the supreme jurisdictions show more and more tendency to publish their 'European' judgments also in English translations. $^{223}$

However, particularly the Czech Constitutional Court has shown that judicial dialogue on horizontal level can involve critical comparative reasoning as well. Its second Lisbon decision is a clear signal that the interaction and mutual influence of national jurisprudence does not necessarily lead to the reception of a specific judgment in the jurisprudence of other courts, but may in fact evoke express rejection. By objecting openly to some of the key arguments of its German counterpart, the Czech Court in its second Lisbon judgment disproved the commonly expressed idea that constitutional courts of Eastern and Central European countries stick to the Bundesverfassungsgericht as a sort of archetype of constitutional court.

Does this contravene the idea of a common European constitutional law? No, on the contrary. With its second Lisbon decision, the Czech court in fact demonstrated the dialectical prospects of comparative reasoning within the multi-levelled cooperation of European constitutional courts. ${ }^{224}$ Its assessment of the German Lisbon decision should be understood as a constructive impulse that may even foster the debate. The Czech Constitutional Court examined the German decision intensely and came to the conclusion that some of the central arguments and assumptions of this decision - particularly those regarding the principle of sovereignty, the European Parliament and the judicial handling of the constitutional eternity clause - were not sufficiently convincing or transferable to be taken up within the framework of the Czech constitutional order. In doing so, the Czech Constitutional Court itself made an important contribution to the discussion about the scope and content of a common European constitutional law. Comparative dialectics between national constitutional courts in Europe have reached a new level of quality.

${ }^{223}$ The German BVerfG issued an English translation for the first time in the European Arrest Warrant case. In the Lisbon- and Honeywell decisions a translation was already available the day the decision was published.

${ }^{224}$ See A. Voßkuhle, supra n. 35. 